\title{
Enantioselective Total synthesis of convolutamydines B and E
}

Tomoaki Nakamura, Shin-ichi Shirokawa, Seijiro Hosokawa, Atsuo Nakazaki, and Susumu Kobayashi* Faculty of Pharmaceutical Sciences, Tokyo University of Science (RIKADAI)

\section{Experimental Section}

General Methods. All non-aqueous reactions were performed under an atmosphere of dry argon in flame-dried glassware unless otherwise indicated. Solvents were distilled under an atmosphere of argon before use and transferred via an oven dried syringe or cannula. Dichloromethane, $N, N$-dimethyl formamide (DMF) and pyridine were distilled from calcium hydride. Tetrahydrofuran (THF) and diethyl ether were distilled from sodium / benzophenone. Titanium tetrachloride was distilled from cupper.

Flash chromatography was performed with BW-127ZH (Fuji Silysia Co. Ltd. Japan). Solvents for chromatography are listed as volume/volume ratios. Analytical thin layer chromatography was performed using commercial silica gel plates (E. Merck, Silica Gel $\left.60 \mathrm{~F}_{254}\right)$

Infrared spectra were recorded on a JASCO FT/IR-410 spectrometer using sodium chloride plates or potassium bromide pellets. Absorbance frequencies are recorded in reciprocal centimeters $\left(\mathrm{cm}^{-1}\right)$. High resolution mass spectra (HRMS) were obtained from the Mass Spectrometry Resource, Hitachi M-80B spectrometer for electron impact (EI) or Applied Biosystems mass spectrometer (API QSTAR pulsar i) for electrospray ionization (ESI). HRMS data are reported as m/e (relative intensity), with accurate mass reported for the molecular ion $\left(\mathrm{M}^{+}\right)$.

${ }^{1} \mathrm{H}$ NMR spectra were acquired at $400 \mathrm{MHz}$ on a JEOL JNM-LD400 spectrometer. Solvent for NMR is used chloroform- $d$, unless the otherwise noted. Chemical shifts are reported in delta $(\delta)$ units in parts per million $(\mathrm{ppm})$ relative to the singlet (7.26 ppm) for chloroform- $d$ or the central line of the triplet at $8.55 \mathrm{ppm}$ for pyridine- $d_{5}$. Splitting patterns are designated as $\mathrm{s}$, singlet; d, doublet; t, triplet; q, quartet; m, multiplet and br, broad. Coupling constants are recorded in $\mathrm{Hertz}(\mathrm{Hz}) .{ }^{13} \mathrm{C}$ NMR spectra were acquired at $100 \mathrm{MHz}$ on a JEOL JNM-LD400 spectrometer. Chemical shifts are reported in ppm relative to the central line of the triplet at $77.0 \mathrm{ppm}$ for chloroform- $d$ or the singlet $(150.0 \mathrm{ppm})$ for pyridine- $d_{5}$. Diastereomeric ratio was determined by ${ }^{1} \mathrm{H}$ NMR analysis.

Chiral HPLC analyses were performed on a GL Science DG660, PU614, CO630, UV660 using Chiralpak column AD with hexane / 2-propanol mixtures with ratio of the eluent, flow rate, and column indicated. Retention time $\left(\tau_{R}\right)$ are reported in minutes (min). Optical rotations were determined using a JASCO P-1030 digital polarimeter in 10-mm cells and the sodium D line $(589 \mathrm{~nm})$ at room temperature in the solvent and concentration indicated. Circular dichroism spectra were recorded on a JASCO J-725 spectrometer using methanol as a solvent. Melting points were recorded on Yanaco MP-3S. 


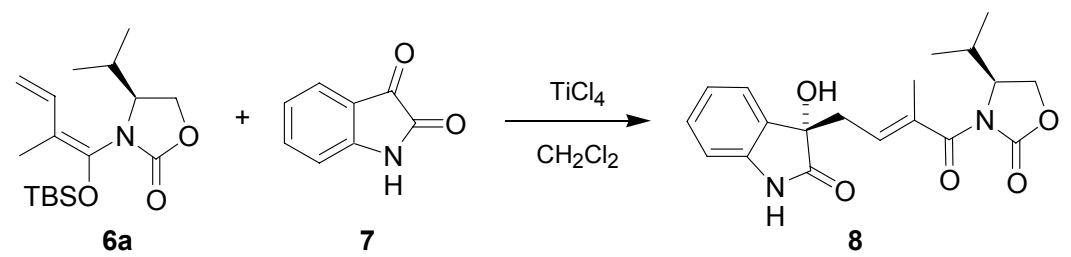

Compound 8. To a solution of isatin $7(271.2 \mathrm{mg}, 1.8 \mathrm{mmol})$ and vinylketene $N, O$-acetal $6 \mathbf{6}(300 \mathrm{mg}, 0.92 \mathrm{mmol})$ in dry dichloromethane $(30 \mathrm{~mL})$ under argon atmosphere was carefully dropped titanium tetrachloride $(0.20 \mathrm{~mL}, 1.8 \mathrm{mmol})$ at $-78^{\circ} \mathrm{C}$. After stirring for $6 \mathrm{hr}$, to the reaction mixture was added pyridine $(0.60 \mathrm{~mL})$. The resulting mixture was poured to the mixture of a saturated aqueous solution of $( \pm)$-sodium potassium tartrate and a saturated aqueous solution of sodium bicarbonate $(1: 1)$ at $0{ }^{\circ} \mathrm{C}$. After the organic layer was clear, aqueous layer was extracted with dichloromethane. The combined extracts were washed with brine, dried over anhydrous sodium sulfate, filtered, and concentrated in vacuo. The residue was purified via column chromatography (Hexane / Ethyl acetate $=4 / 1$ ) to yield $201 \mathrm{mg}$ of alcohol $8(61 \%)$ as a $40: 1$ diastereomeric mixture. TLC, $R_{f}=0.10\left(\right.$ Hexane / Ethyl acetate = 1/ 1); IR (neat) 3299, 2967, 1779, 1721, 1687, $1623 \mathrm{~cm}^{-1} ;{ }^{1} \mathrm{H} \mathrm{NMR}(400 \mathrm{MHz}) \delta$ $0.87(\mathrm{~d}, J=6.8 \mathrm{~Hz}, 3 \mathrm{H}), 0.90(\mathrm{~d}, J=7.1 \mathrm{~Hz}, 3 \mathrm{H}), 1.91(\mathrm{~s}, 3 \mathrm{H}), 2.27-2.35(\mathrm{~m}, 1 \mathrm{H}), 2.69(\mathrm{dd}, J=6.1,14.4 \mathrm{~Hz}, 1 \mathrm{H}), 2.82(\mathrm{dd}, J$ $=9.3,14.4 \mathrm{~Hz}, 1 \mathrm{H}), 4.18(\mathrm{dd}, J=5.1,9.0 \mathrm{~Hz}, 1 \mathrm{H}), 4.31(\mathrm{dd}, J=8.8,9.0 \mathrm{~Hz}, 1 \mathrm{H}), 4.37(\mathrm{br}, 1 \mathrm{H}), 4.46-4.51(\mathrm{~m}, 1 \mathrm{H}), 6.13(\mathrm{dd}, J$ $=6.1,9.3 \mathrm{~Hz}, 1 \mathrm{H}), 6.86(\mathrm{~d}, J=7.6 \mathrm{~Hz}, 1 \mathrm{H}), 7.04(\mathrm{t}, J=7.6 \mathrm{~Hz}, 1 \mathrm{H}), 7.22(\mathrm{t}, J=7.6 \mathrm{~Hz}, 1 \mathrm{H}), 7.40(\mathrm{~d}, J=7.6 \mathrm{~Hz}, 1 \mathrm{H}), 8.68(\mathrm{br}$, $1 \mathrm{H}) ;{ }^{13} \mathrm{C}$ NMR (100 MHz) $\delta 13.8,14.8,17.7,28.2,37.0,58.1,63.5,76.0,110.3,122.9,124.1,129.6,129.7,130.6,135.3$, 140.4, 153.8, 171.4, 179.6; $[\alpha]_{\mathrm{D}}+31.5$ (c 1.53, MeOH); HRMS (ESI) calcd for $\mathrm{C}_{19} \mathrm{H}_{22} \mathrm{~N}_{2} \mathrm{NaO}_{5}\left(\mathrm{M}^{+}\right) 381.1426$, found 381.1413.

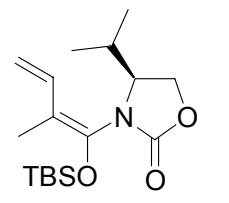

6a

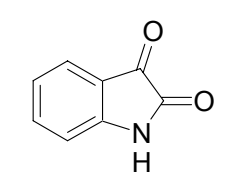

7

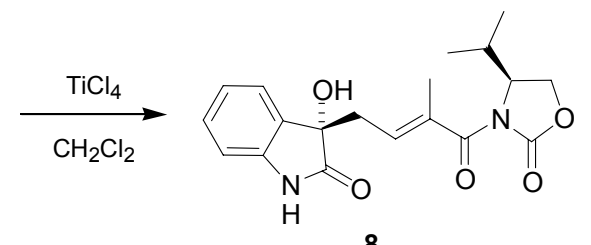

8

Method A; To a solution of isatin $7(271 \mathrm{mg}, 1.84 \mathrm{mmol})$ in dry dichloromethane $(55 \mathrm{~mL})$ under argon atmosphere was carefully dropped titanium tetrachloride $\left(0.60 \mathrm{~mL}, 1.0 \mathrm{M}\right.$ in dichloromethane) at $-78{ }^{\circ} \mathrm{C}$, then the color was turned yellow. After stirring for $30 \mathrm{~min}$, the solution of vinylketene $N, O$-acetal $\mathbf{6 a}(100 \mathrm{mg}, 0.3 \mathrm{mmol})$ in dry dichloromethane $(5 \mathrm{~mL})$ was added dropwise. After stirring for $6 \mathrm{hr}$, to the reaction mixture was pyridine $(0.20 \mathrm{~mL})$. The resulting mixture was poured to the mixture of a saturated aqueous solution of $( \pm)$-sodium potassium tartrate and a saturated aqueous solution of sodium bicarbonate $(1: 1)$ at $0{ }^{\circ} \mathrm{C}$. After the organic layer was clear, aqueous layer was extracted with dichloromethane. The combined extracts were washed with brine, dried over anhydrous sodium sulfate, filtered, and concentrated in vacuo. The residue was purified via column chromatography (Hexane / Chloroform / Ethyl acetate $=3 / 1 / 1)$ to yield $99 \mathrm{mg}$ of alcohol $8(90 \%)$ as a $31: 1$ diastereomeric mixture. Method B; To a solution of isatin 7 (271 mg, $1.84 \mathrm{mmol})$ in dry dichloromethane (55 mL) under argon atmosphere was carefully dropped titanium tetrachloride $\left(0.60 \mathrm{~mL}, 1.0 \mathrm{M}\right.$ in dichloromethane) at $-78{ }^{\circ} \mathrm{C}$. After stirring for $30 \mathrm{~min}$ at $0{ }^{\circ} \mathrm{C}$, the solution of vinylketene $N, O$-acetal $\mathbf{6 a}(100 \mathrm{mg}, 0.3 \mathrm{mmol})$ in dry dichloromethane $(5 \mathrm{~mL})$ was added dropwise at $-78{ }^{\circ} \mathrm{C}$. After stirring for $6 \mathrm{hr}$, to the reaction mixture was added pyridine $(0.20 \mathrm{~mL})$. The resulting mixture was 
poured to the mixture of a saturated aqueous solution of $( \pm)$-sodium potassium tartrate and a saturated aqueous solution of sodium bicarbonate $(1: 1)$ at $0{ }^{\circ} \mathrm{C}$. When the organic layer was clear, aqueous layer was extracted with dichloromethane. The combined extracts were washed with brine, dried over anhydrous sodium sulfate, filtered, and concentrated in vacuo. The residue was purified via column chromatography (Hexane / Chloroform / Ethyl acetate $=3 / 1 / 1)$ to yield $76 \mathrm{mg}$ of alcohol 8 $(69 \%)$ as a $60: 1$ diastereomeric mixture.

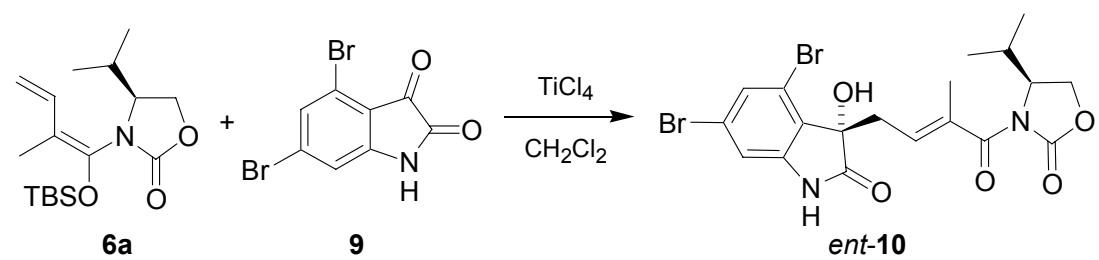

Compound ent-10. Method A; To a solution of 4,6-dibromoisatin $9(562 \mathrm{mg}, 1.84 \mathrm{mmol})$ in dry dichloromethane $(50 \mathrm{~mL})$ under argon atmosphere was carefully dropped titanium tetrachloride $(0.60 \mathrm{~mL}, 1.0 \mathrm{M}$ in dichloromethane $)$ at $-78{ }^{\circ} \mathrm{C}$, then the color was turned yellow. After stirring for $30 \mathrm{~min}$, the solution of vinylketene $\mathrm{N}, O$-acetal 6a $(100 \mathrm{mg}, 0.31 \mathrm{mmol})$ in dry dichloromethane $(10 \mathrm{~mL})$ was added dropwise. After stirring for $6 \mathrm{hr}$, to the reaction mixture was added pyridine $(0.20 \mathrm{~mL})$. The resulting mixture was poured to the mixture of a saturated aqueous solution of $( \pm)$-sodium potassium tartrate and a saturated aqueous solution of sodium bicarbonate $(1: 1)$ at $0{ }^{\circ} \mathrm{C}$. After the organic layer was clear, aqueous layer was extracted with dichloromethane. The combined extracts were washed with brine, dried over anhydrous sodium sulfate, filtered, and concentrated in vacuo. The residue was purified via column chromatography (Hexane / Chloroform $/$ Ethyl acetate $=3 / 1 / 1)$ to yield $71 \mathrm{mg}$ of alcohol ent-10 (45\%) as a $13: 1$ diastereomeric mixture. Method B; To a solution of 4,6-dibromoisatin 9 $(562 \mathrm{mg}, 1.84 \mathrm{mmol})$ in dry dichloromethane $(50 \mathrm{~mL})$ under argon atmosphere was carefully dropped titanium tetrachloride $\left(0.60 \mathrm{~mL}, 1.0 \mathrm{M}\right.$ in dichloromethane) at $-78{ }^{\circ} \mathrm{C}$. After stirring for $30 \mathrm{~min}$ at $0{ }^{\circ} \mathrm{C}$, the solution of vinylketene $N, O$-acetal 6 a $(100 \mathrm{mg}, 0.31 \mathrm{mmol})$ in dry dichloromethane $(10 \mathrm{~mL})$ was added dropwise at $-78{ }^{\circ} \mathrm{C}$. After stirring for $6 \mathrm{hr}$, to the reaction mixture was added pyridine $(0.20 \mathrm{~mL})$. The resulting mixture was poured to the mixture of a saturated aqueous solution of $( \pm)$-sodium potassium tartrate and a saturated aqueous solution of sodium bicarbonate $(1: 1)$ at $0{ }^{\circ} \mathrm{C}$. After the organic layer was clear, aqueous layer was extracted with dichloromethane. The combined extracts were washed with brine, dried over anhydrous sodium sulfate, filtered, and concentrated in vacuo. The residue was purified via column chromatography (Hexane / Chloroform / Ethyl acetate $=3 / 1 / 1$ ) to yield $158 \mathrm{mg}$ of alcohol ent-10 (quantitatively) as a $70: 1$ diastereomeric mixture. TLC, $R_{f}=0.17$ (Hexane / Ethyl acetate $=1 / 1$ ); m.p. 74 80 ${ }^{\circ} \mathrm{C}$; IR (neat) $3281,2964,1782,1736,1685,1607,1575 \mathrm{~cm}^{-1} ;{ }^{1} \mathrm{H}$ NMR (400 MHz) $\delta 0.88(\mathrm{~d}, J=7.1 \mathrm{~Hz}, 3 \mathrm{H}), 0.92(\mathrm{~d}, J=7.1 \mathrm{~Hz}, 3 \mathrm{H}), 2.01(\mathrm{~s}, 3 \mathrm{H}), 2.34$ (d sept, $J=4.2,7.1 \mathrm{~Hz}, 1 \mathrm{H}), 2.70$ (dd, $J=5.8,13.9 \mathrm{~Hz}, 1 \mathrm{H}), 3.38(\mathrm{dd}, J=9.8,13.9 \mathrm{~Hz}, 1 \mathrm{H}), 4.20(\mathrm{br}, 1 \mathrm{H}), 4.21(\mathrm{dd}, J=5.1,9.0 \mathrm{~Hz}, 1 \mathrm{H}), 4.34$ (dd, $J=8.8,9.0 \mathrm{~Hz}$, 1H), $4.51(\mathrm{ddd}, J=4.2,5.1,8.8 \mathrm{~Hz}, 1 \mathrm{H}), 5.92(\mathrm{dd}, J=5.8,9.8 \mathrm{~Hz}, 1 \mathrm{H}), 6.96(\mathrm{~d}, J=1.2 \mathrm{~Hz}, 1 \mathrm{H}), 7.36(\mathrm{~d}, J=1.2 \mathrm{~Hz}, 1 \mathrm{H}), 8.18$ (br, 1H); ${ }^{13} \mathrm{C}$ NMR (100 MHz) $\delta 13.9,14.8,17.8,28.3,33.8,58.0,63.6,77.2,113.0,119.9,123.8,127.1,127.5,129.3,136.4$, 143.3, 153.9, 171.4, 178.3; $[\alpha]_{\mathrm{D}}-87.3$ (c 1.00, MeOH); HRMS (EI) calcd for $\mathrm{C}_{19} \mathrm{H}_{20} \mathrm{Br}_{2} \mathrm{~N}_{2} \mathrm{O}_{5}\left(\mathrm{M}^{+}\right)$513.9739, 515.9719, 517.9698, found 513.9730, 515.9750. 


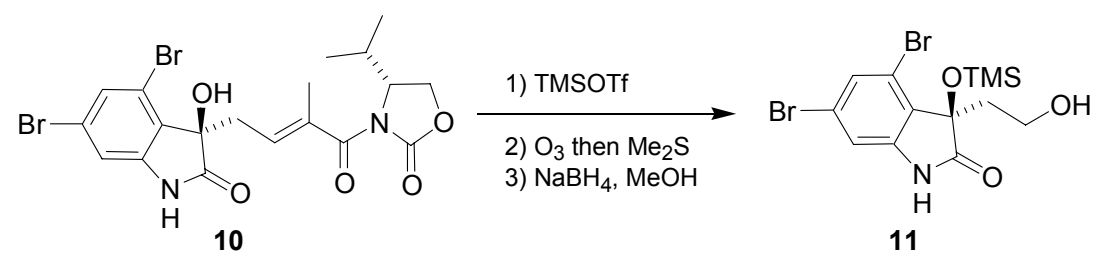

Compound 11. To a solution of alcohol $10(281 \mathrm{mg}, 0.54 \mathrm{mmol})$ in dry dichloromethane $(5.5 \mathrm{~mL})$ was added 2,6-lutidine $(0.8$ $\mathrm{mL}, 3.3 \mathrm{mmol})$ and trimethylsilyl trifluoromethanesulfonate $(0.12 \mathrm{~mL}, 1.36 \mathrm{mmol})$ at $-30^{\circ} \mathrm{C}$. After stirring at $0{ }^{\circ} \mathrm{C}$ for $3 \mathrm{hr}$, the reaction was quenched with a saturated aqueous solution of sodium bicarbonate, extracted with dichloromethane, washed with brine, dried over anhydrous sodium sulfate, filtered, and concentrated in vacuo. The residue was purified via column chromatography to afford the silyl ether as white solid. Ozone was bubbled through a solution of the silyl ether in dichloromethane $(10 \mathrm{~mL})$ at $-78^{\circ} \mathrm{C}$. The reaction progress was monitored via TLC (every five minutes a TLC was taken) until complete consumption of starting material was observed. At that time, the excess ozone was removed by bubbling argon through the solution. Dimethyl sulfide $(0.4 \mathrm{~mL})$ was added and the reaction was stirred at $0{ }^{\circ} \mathrm{C}$ for 15 min. The resulting solution was concentrated in vacuo and purified directly via flash chromatography to afford the corresponding aldehyde. To a solution of the aldehyde in methanol $(5.6 \mathrm{~mL})$ was added sodium borohydride $(27 \mathrm{mg}, 0.71 \mathrm{mmol})$ at $0{ }^{\circ} \mathrm{C}$, stirred for $2 \mathrm{hr}$. The reaction was quenched with a saturated aqueous solution of ammonium chloride, extracted with ethyl acetate. The combined organic layer was washed with brine, dried over anhydrous sodium sulfate, filtered, and concentrated in vacuo. The residue was purified via column chromatography to yield $113 \mathrm{mg}$ of alcohol 11 ( $49 \%$ in 3 steps). TLC, $R_{f}=0.45$ (Hexane / Ethyl acetate $=1 / 1$ ); m.p. $148 \sim 151{ }^{\circ} \mathrm{C}$; IR (neat) $3454,3135,2952,2885,1735,1606,1573 \mathrm{~cm}^{-1} ;{ }^{1} \mathrm{H}$ NMR (400 MHz) $\delta 0.02(\mathrm{~s}$, 9H), 1.26 (br, 1H), 2.25 (ddd, $J=3.4,5.6,14.4 \mathrm{~Hz}, 1 \mathrm{H}), 2.59$ (ddd, $J=4.2,8.8,14.4 \mathrm{~Hz}, 1 \mathrm{H}), 3.59$ (ddd, $J=3.4,8.8,11.8 \mathrm{~Hz}$, 1H), 3.89 (ddd, $J=4.2,5.6,11.8 \mathrm{~Hz}, 1 \mathrm{H}), 6.96(\mathrm{~d}, J=1.5 \mathrm{~Hz}, 1 \mathrm{H}), 7.36(\mathrm{~d}, J=1.5 \mathrm{~Hz}, 1 \mathrm{H}), 8.86(\mathrm{br}, 1 \mathrm{H}) ;{ }^{13} \mathrm{C} \mathrm{NMR}(100$ MHz) $\delta 1.0,38.9,58.2,78.6,113.1,120.4,123.8,128.0,129.6,142.7,179.6 ;[\alpha]_{\mathrm{D}}+7.8(c$ 0.20, MeOH); HRMS (EI) calcd for $\mathrm{C}_{13} \mathrm{H}_{17} \mathrm{Br}_{2} \mathrm{NO}_{3} \mathrm{Si}\left(\mathrm{M}^{+}\right)$420.9344, 422.9324, 424.9303, found 420.9333, 422.9330.
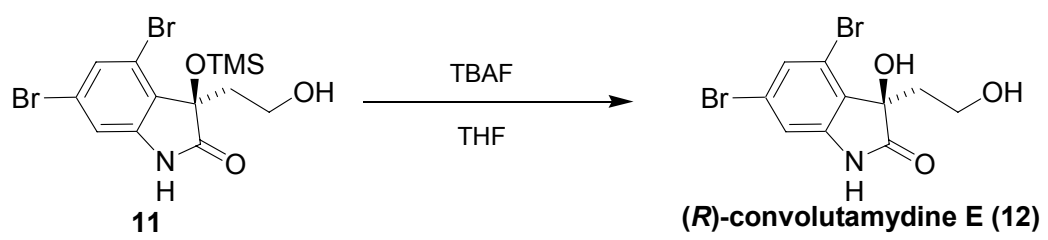

(R)-Convolutamydine E (12). To a solution of alcohol $11(37.8 \mathrm{mg}, 0.11 \mathrm{mmol})$ in dry THF $(2.0 \mathrm{~mL})$ was added tetrabutylammonium fluoride $\left(0.14 \mathrm{~mL}, 1.0 \mathrm{M}\right.$ in tetrahydrofuran) at $0{ }^{\circ} \mathrm{C}$ under argon atmosphere. After stirring for $30 \mathrm{~min}$, the reaction was quenched with a saturated aqueous solution of ammonium chloride, extracted with diethyl ether, washed with brine, dried over anhydrous sodium sulfate, filtered, and concentrated in vacuo. The residue was purified via column chromatography (Chloroform / Methanol = $30 / 1)$ to yield $31 \mathrm{mg}$ of $(R)$-convolutamydine E (12) as a white solid (99\%). TLC, $R_{f}=0.22($ Hexane / Ethyl acetate $=1 / 2)$; m.p. $132 \sim 133{ }^{\circ} \mathrm{C}$; IR $(\mathrm{KBr}) 3437,3134,2940,1757,1615,1573 \mathrm{~cm}^{-1} ;{ }^{1} \mathrm{H}$ NMR (400 MHz, pyridine- $\left.d_{5}\right) ; \delta 3.20(\mathrm{t}, J=6.8 \mathrm{~Hz}, 2 \mathrm{H}), 3.62(\mathrm{~s}, 1 \mathrm{H}), 4.00-4.04(\mathrm{~m}, 2 \mathrm{H}), 7.12(\mathrm{~d}, J=1.4 \mathrm{~Hz}, 1 \mathrm{H}), 7.47(\mathrm{~d}, J=1.4$ $\mathrm{Hz}, 1 \mathrm{H}), 8.49$ (br, 1H), 12.1 (br, 1H); ${ }^{13} \mathrm{C}$ NMR (100 MHz, pyridine- $\left.d_{5}\right) \delta 39.2,58.0,77.3,112.6,120.8,128.0,130.1,130.1$, 146.7, 180.6; $[\alpha]_{\mathrm{D}}+12.6$ (c 1.00, MeOH); HRMS (EI) calcd for $\mathrm{C}_{10} \mathrm{H}_{9} \mathrm{Br}_{2} \mathrm{NO}_{3}\left(\mathrm{M}^{+}\right)$348.8949, 350.8929, 352.8908, found $348.8950,350.8959,352.8924$ : Our synthetic sample was a white solid, although it was reported that natural sample was a 
colorless oil.

HPLC (Daicel Chiralpak AD, flow rate $=0.8 \mathrm{~mL} / \mathrm{min}$, Hexane $/ i \mathrm{PrOH}=5 / 1,254 \mathrm{~nm}$ )

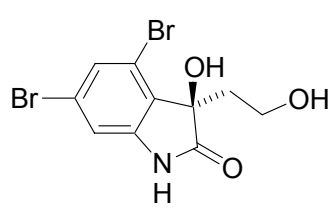

12

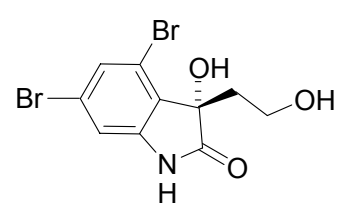

ent-12
Synthetic $(R)$-convolutamydine $\mathrm{E}$

Synthetic $(S)$-convolutamydine E

Racemic
$14.80 \mathrm{~min}$

$15.28 \mathrm{~min}$

$15.02 \mathrm{~min}$
$19.72 \mathrm{~min}$

$19.31 \mathrm{~min}$

$19.59 \mathrm{~min}$
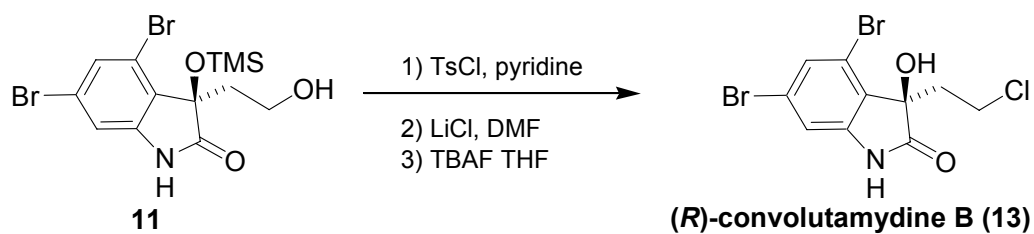

(R)-convolutamydine B (13)

(R)-Convolutamydine B (13). To a solution of alcohol $11(30 \mathrm{mg}, 0.07 \mathrm{mmol})$ in dry pyridine $(1.8 \mathrm{~mL})$ was added $p$-toluenesulfonyl chloride (54 mg, $0.28 \mathrm{mmol}$ ) at room temperature. After stirring at $80{ }^{\circ} \mathrm{C}$ for $2 \mathrm{hr}$, the reaction was quenched with $1 \mathrm{~N} \mathrm{HCl}$, extracted with ethyl acetate, washed with a saturated aqueous solution of sodium bicarbonate and brine. The organic layer was dried over anhydrous sodium sulfate, filtered, and concentrated in vacuo. The residue was purified via column chromatography (Hexane / Ethyl acetate $=3 / 1$ ) to afford the corresponding tosylate. The mixture of the resulting tosylate and lithium chloride $(8.6 \mathrm{mg}, 0.203 \mathrm{mmol})$ in DMF $(1.3 \mathrm{~mL})$ was stirred at $80{ }^{\circ} \mathrm{C}$ for $5 \mathrm{hr}$. The reaction mixture was directly concentrated in vacuo. The residue was purified via column chromatography (Hexane / Ehtyl acetate $=4 / 1)$ to afford chloride. To a solution of the chloride in dry THF $(3.6 \mathrm{~mL})$ was added tetrabutylammonium fluoride $(0.04 \mathrm{~mL}, 1.0 \mathrm{M}$ in THF) at $0{ }^{\circ} \mathrm{C}$, then stirred for $30 \mathrm{~min}$ at the same temperature. The reaction was quenched with a saturated aqueous solution of ammonium chloride, extracted with diethyl ether, washed with brine, dried over anhydrous sodium sulfate, filtered, and concentrated in vacuo. The residue was purified via column chromatography, then recrystallized from chloroform to yield 10.5 mg of $(R)$-convolutamydine B (13) as a white solid $\left(40 \%\right.$ over 3 steps). TLC, $R_{f}=0.45$ (Hexane $/$ Ethyl acetate $\left.=1 / 1\right)$; m.p. 204 205 ${ }^{\circ} \mathrm{C}$; IR (KBr) 3324, 1711, 1608, $1583 \mathrm{~cm}^{-1} ;{ }^{1} \mathrm{H}$ NMR (400 MHz) $\delta 2.65$ (ddd, $\left.J=7.3,8.8,13.9 \mathrm{~Hz}, 1 \mathrm{H}\right), 2.74$ (ddd, $J$ $=5.6,8.5,13.9 \mathrm{~Hz}, 1 \mathrm{H}), 3.35-3.40(\mathrm{~m}, 1 \mathrm{H}), 3.40-3.45(\mathrm{~m}, 1 \mathrm{H}), 7.00(\mathrm{~d}, J=1.5 \mathrm{~Hz}, 1 \mathrm{H}), 7.34(\mathrm{~d}, J=1.5 \mathrm{~Hz}, 1 \mathrm{H}), 9.94(\mathrm{br}$, $1 \mathrm{H}) ;{ }^{1} \mathrm{H}$ NMR $\left(400 \mathrm{MHz}, \mathrm{CDCl}_{3} / \mathrm{CD}_{3} \mathrm{OD}=5 / 1\right) \delta 2.65(\mathrm{ddd}, J=7.2,8.8,14.0 \mathrm{~Hz}, 1 \mathrm{H}), 2.75(\mathrm{ddd}, J=5.6,8.4,14.0 \mathrm{~Hz}, 1 \mathrm{H})$, $3.38(\mathrm{ddd}, J=7.2,8.4,11.2 \mathrm{~Hz}, 1 \mathrm{H}), 3.44(\mathrm{ddd}, J=5.6,8.8,11.2 \mathrm{~Hz}, 1 \mathrm{H}), 3.70(\mathrm{br}, 1 \mathrm{H}), 7.01(\mathrm{~d}, J=1.7 \mathrm{~Hz}, 1 \mathrm{H}), 7.34(\mathrm{~d}, J=$ $1.7 \mathrm{~Hz}, 1 \mathrm{H}), 7.38(\mathrm{~s}, 1 \mathrm{H}) ;{ }^{1} \mathrm{H}$ NMR (400 MHz, acetone- $\left.d_{6}\right) \delta 2.69(\mathrm{dd}, J=7.4,8.6 \mathrm{~Hz}, 2 \mathrm{H}), 3.56(\mathrm{ddd}, J=7.4,8.6,11.3 \mathrm{~Hz}$, 1H), 3.62 (ddd, $J=7.4,8.6,11.3 \mathrm{~Hz}, 1 \mathrm{H}), 7.12$ (d, $J=1.7 \mathrm{~Hz}, 1 \mathrm{H}), 7.37$ (d, $J=1.7 \mathrm{~Hz}, 1 \mathrm{H}), 9.69$ (br, $1 \mathrm{H}) ;{ }^{13} \mathrm{C}$ NMR $(100$ $\mathrm{MHz}) \delta 38.1,57.8,77.0,112.8,120.6,123.2,128.3,129.3,146.0,178.6 ;{ }^{13} \mathrm{C} \mathrm{NMR}\left(100 \mathrm{MHz}, \mathrm{CDCl}_{3} / \mathrm{CD}_{3} \mathrm{OD}=5 / 1\right) \delta 37.4$, $38.5,76.4,112.8,119.9,123.7,127.0,128.8,144.2,178.9 ;{ }^{13} \mathrm{C}$ NMR $\left(100 \mathrm{MHz}\right.$, acetone- $\left.d_{6}\right) \delta 38.8,39.6,77.0,113.4,120.8$, 124.0, 128.8, 128.9, 146.1, 177.8; $[\alpha]_{\mathrm{D}}-1.28$ (c 0.82, MeOH); HRMS (EI) calcd for $\mathrm{C}_{10} \mathrm{H}_{8} \mathrm{Br}_{2} \mathrm{ClNO}_{2}\left(\mathrm{M}^{+}\right) 366.8610,368.8590$, 370.8569, found 366.8604: For the melting point and the optical rotation, our synthetic sample (m.p. $204 \sim 205{ }^{\circ} \mathrm{C},[\alpha]_{\mathrm{D}}-1.28$ ) was distinguished from natural sample (m.p. $225 \sim 227^{\circ} \mathrm{C},[\alpha]_{\mathrm{D}}+18.1$ ). 
HPLC (Daicel Chiralpak AD, flow rate $=0.8 \mathrm{~mL} / \mathrm{min}$, Hexane $/ i \mathrm{PrOH}=10 / 1,254 \mathrm{~nm}$ )<smiles>O=C1Nc2cc(Br)cc(Br)c2[C@@]1(O)CCCl</smiles>

13<smiles>O=C1Nc2cc(Br)cc(Br)c2[C@@]1(O)CCCl</smiles>

ent-13
$99 \%$ e.e.

$>99 \%$ e.e.

Synthetic $(S)$-convolutamydine B

$18.27 \mathrm{~min}$

$23.79 \mathrm{~min}$

$23.54 \mathrm{~min}$

$23.76 \mathrm{~min}$

Racemic

$18.50 \mathrm{~min}$

[Determination of stereochemistries of Vinylogous Mukaiyama Aldol Reaction]

The aldol adduct $\mathbf{8}$ was confirmed to have an $E$-configuration by an nOe experiment. Furthermore, the stereochemistry of $\mathbf{8}$ was unambiguously determined by correlating to 3a-hydroxyfuroindoline $14,{ }^{1}$ afford in three steps.

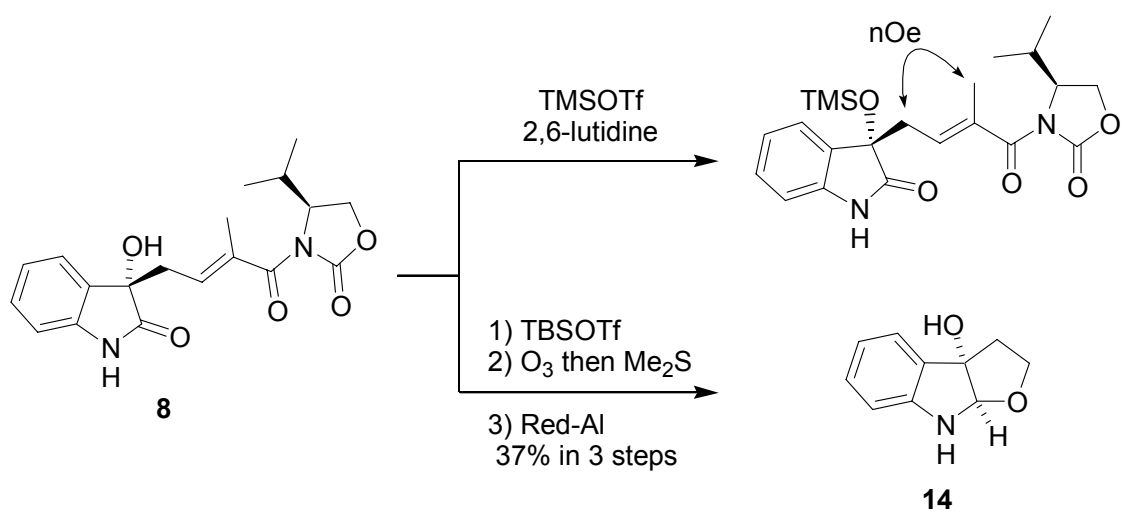

To determine the stereochemistry of the 3-position in $(S)$-convolutamydine $\mathrm{E}$ (ent-12), ent-12 was converted into debromoderivative $\mathbf{1 5}$ in the three-step sequence. The resulting derivative $\mathbf{1 5}$ was identical to $\mathbf{1 5}$ prepared from aldol adduct $\mathbf{8}$ by chiral HPLC analysis.

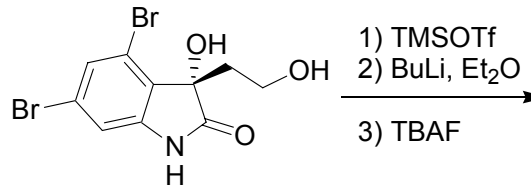

ent-12

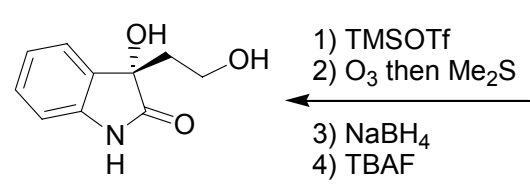

15<smiles>C/C(=C\C[C@]1(O)C(=O)Nc2ccccc21)C(=O)N1C(=O)OC[C@H]1C(C)C</smiles>

8 


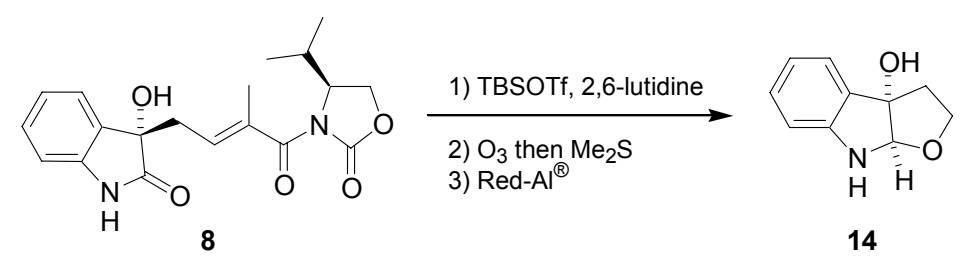

(3aS,8aS)-3a-Hydroxyfuroindoline (14). To a solution of alcohol $8(120 \mathrm{mg}, 0.33 \mathrm{mmol})$ in dry dichloromethane $(5 \mathrm{~mL})$ under argon atmosphere were added 2,6-lutidine $(0.19 \mathrm{~mL}, 0.77 \mathrm{mmol})$ and tert-butyldimethylsilyl trifluoromethanesulfonate $(0.45 \mathrm{~mL}, 1.98 \mathrm{mmol})$ at $-30{ }^{\circ} \mathrm{C}$, stirred at $0{ }^{\circ} \mathrm{C}$ for $14 \mathrm{hr}$. The reaction was quenched with a saturated aqueous solution of sodium bicarbonate, then extracted with dichloromethane. The combined organic layer was washed by brine, dried over anhydrous sodium sulfate, filtered, and concentrated in vacuo. The residue was purified via column chromatography to afford the silyl ether as white solid. Ozone was bubbled through a solution of the silyl ether in dichloromethane $(5 \mathrm{~mL})$ at $-78{ }^{\circ} \mathrm{C}$. The reaction progress was monitored via TLC (every five minutes a TLC was taken) until complete consumption of starting material was observed. At that time, the excess ozone was removed by bubbling argon through the solution. Dimethyl sulfide $(2 \mathrm{~mL})$ was added and the reaction was stirred at $0{ }^{\circ} \mathrm{C}$ for $15 \mathrm{~min}$. The resulting solution was concentrated in vacuo and purified directly via flash chromatography to afford the corresponding aldehyde. To a solution of the aldehyde in dry THF (2 $\mathrm{mL}$ ) was added Red-Al ${ }^{\circledR}\left(0.36 \mathrm{~mL}, 0.45 \mathrm{M}\right.$ in THF) at $0{ }^{\circ} \mathrm{C}$, stirred for $2.5 \mathrm{hr}$. The reaction was quenched with $1 \mathrm{~N} \mathrm{HCl}$, stirred for 30 min, added $2 \mathrm{~N} \mathrm{NaOH}$ until $\mathrm{pH} 10$ and extracted with chloroform. The combined organic layer was washed with brine, dried over anhydrous sodium sulfate, filtered, and concentrated in vacuo. The residue was purified via column chromatography, then recrystallized from diethyl ether to yield $21.6 \mathrm{mg}$ of furoindoline 14 (37\% in 3 steps, $98 \%$ e.e.). TLC, $R_{f}=0.11$ (Hexane / Ethyl acetate $=2 / 1):{ }^{1} \mathrm{H}$ NMR $(400 \mathrm{MHz}) \delta 2.36(\mathrm{ddd}, J=2.2,5.4,12.0 \mathrm{~Hz}, 1 \mathrm{H}), 2.48(\mathrm{ddd}, J=7.6,11.0,12.0 \mathrm{~Hz}, 1 \mathrm{H}), 3.19$ (br, 1H), 3.69 (ddd, $J=5.4,9.0,11.0 \mathrm{~Hz}, 1 \mathrm{H}), 4.08$ (ddd, $J=2.2,7.6,9.0 \mathrm{~Hz}, 1 \mathrm{H}), 4.60$ (br, 1H), 5.45 (s, 1H), 6.64 (d, $J=7.6$ $\mathrm{Hz}, 1 \mathrm{H}), 6.82(\mathrm{t}, J=7.6 \mathrm{~Hz}, 1 \mathrm{H}), 7.18(\mathrm{dt}, J=1.5,7.6 \mathrm{~Hz}, 1 \mathrm{H}), 7.33(\mathrm{dt}, J=7.6,1.5 \mathrm{~Hz}, 1 \mathrm{H}) ;[\alpha]_{\mathrm{D}}+182\left(c 0.85, \mathrm{CHCl}_{3}\right):$ lit. $^{1}$ $[\alpha]_{\mathrm{D}}-144\left(c 0.84, \mathrm{CHCl}_{3}\right.$ : for ent-14).

HPLC (Daicel Chiralpak AD, flow rate $=0.5 \mathrm{~mL} / \mathrm{min}$, Hexane $/ i \operatorname{PrOH}=9 / 1,254 \mathrm{~nm}$ )

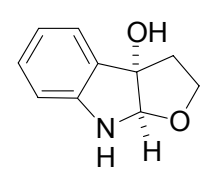

14

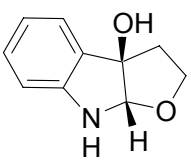

ent-14

\section{Prepared from 8}

Prepared from Tryptophol ${ }^{1}$

Racemic

$$
31.44 \mathrm{~min}
$$

$31.68 \mathrm{~min}$

$31.42 \mathrm{~min}$
$45.18 \mathrm{~min}$

$45.10 \mathrm{~min}$

$45.36 \mathrm{~min}$

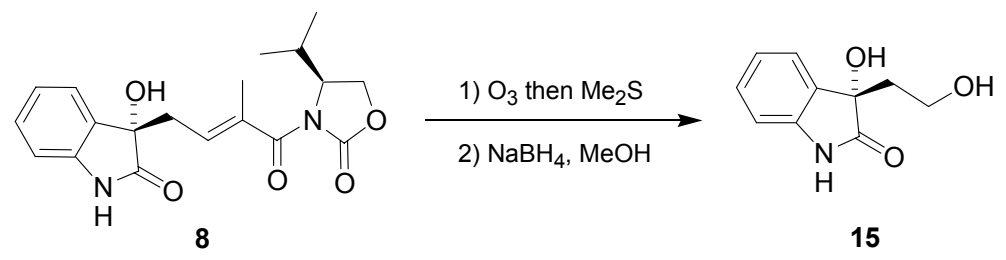

(S)-Debromoconvolutamydine E (15). Ozone was bubbled through a solution of alcohol 8 (100 $\mathrm{mg}, 0.28 \mathrm{mmol})$ in dichloromethane $(12 \mathrm{~mL})$ at $-78^{\circ} \mathrm{C}$. The reaction progress was monitored via TLC (every five min a TLC was taken) until 
complete consumption of starting material was observed. At that time, the excess ozone was removed by bubbling argon through the solution. Dimethyl sulfide $(4 \mathrm{~mL})$ was added and the reaction was stirred at $0{ }^{\circ} \mathrm{C}$ for $15 \mathrm{~min}$. The resulting solution was concentrated in vacuo and purified directly via flash chromatography to afford the corresponding aldehyde. To a solution of the aldehyde in methanol $(3 \mathrm{~mL})$ was added sodium borohydride $(12 \mathrm{mg}, 0.32 \mathrm{mmol})$ at $0{ }^{\circ} \mathrm{C}$, stirred for $2 \mathrm{hr}$. The reaction was quenched with a saturated aqueous solution of ammonium chloride, extracted with ethyl acetate. The combined organic layer was washed with brine, dried over anhydrous sodium sulfate, filtered, and concentrated in vacuo. The residue was purified via column chromatography (Chloroform / Methanol = 30 / 1) to yield $32 \mathrm{mg}$ of $(S)$-debromoconvolutamydine E (15) as a white solid (67\% in 2 steps). TLC, $R_{f}=0.15$ (Hexane / Ethyl acetate $\left.=1 / 2\right) ;{ }^{1} \mathrm{H} \mathrm{NMR}(400 \mathrm{MHz}) \delta 2.24-2.35(\mathrm{~m}, 2 \mathrm{H})$, 3.94-4.15 (m, 2H), $6.87(\mathrm{~d}, J=8.4 \mathrm{~Hz}, 1 \mathrm{H}), 7.09$ (t, $J=7.2 \mathrm{~Hz}, 1 \mathrm{H}), 7.25-7.27(\mathrm{~m}, 1 \mathrm{H}), 7.40(\mathrm{~d}, J=7.5 \mathrm{~Hz}, 1 \mathrm{H}) ;{ }^{13} \mathrm{C} \mathrm{NMR}$ $(100 \mathrm{MHz}) \delta 39.1,58.6,77.2,110.3,123.3,124.3,129.8,131.0,139.8,166.6$; IR (neat) $3433,1717,1621 \mathrm{~cm}^{-1} ;[\alpha]_{\mathrm{D}}-14.7(c$ 0.21, $\mathrm{MeOH}$ ); HRMS (EI) calcd for $\mathrm{C}_{10} \mathrm{H}_{11} \mathrm{NO}_{3}\left(\mathrm{M}^{+}\right)$193.0739, found 193.0737.

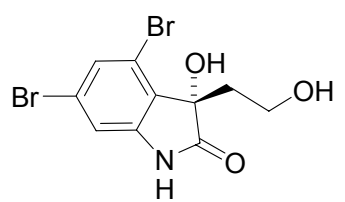

(S)-convolutamydine E (ent-13)

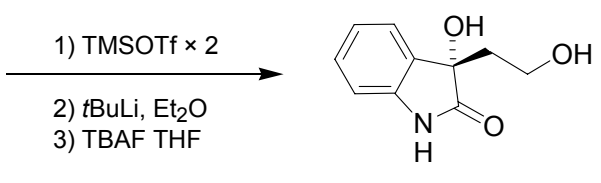

15

$(S)$-Debromoconvolutamydine E (15). To a solution of $(S)$-convolutamydine E (ent-13, $19.1 \mathrm{mg}, 0.05 \mathrm{mmol}$ ) and 2,6-lutidine $(0.05 \mathrm{~mL}, 0.2 \mathrm{mmol})$ in dry dichloromethane $(2 \mathrm{~mL})$ was added trimethylsilyl trifluoromethanesulfonate $(0.05 \mathrm{~mL}, 0.51 \mathrm{mmol})$ at $0{ }^{\circ} \mathrm{C}$, then stirred for $3 \mathrm{hr}$. The reaction was quenched with a saturated aqueous solution of sodium bicarbonate, extracted with dichloromethane, washed with brine, dried over anhydrous sodium sulfate, filtered, and concentrated in vacuo. The residue was purified via chromatography to afford disilylated convolutamydine E (17.2 $\mathrm{mg}, 77 \%)$. The resulting silyl ether was dissolved in diethyl ether $(1.5 \mathrm{~mL})$, treated by tert-butyllithium $(0.15 \mathrm{~mL}, 1.47 \mathrm{M}$ in hexane $)$ at $-78{ }^{\circ} \mathrm{C}$. The reaction mixture was stirred for $6 \mathrm{hr}$ at the same temperature, quenched with acetic acid (1.0 M in methanol), and concentrated in vacuo. The residue was dissolved in THF $(2.4 \mathrm{~mL})$, added tetrabutylammonium fluoride $\left(0.1 \mathrm{~mL}, 1.0 \mathrm{M}\right.$ in THF) at $0{ }^{\circ} \mathrm{C}$. The reaction was quenched with acetic acid (1.0 $\mathrm{M}$ in methanol), and purified via column chromatography to yield $3.6 \mathrm{mg}$ of (S)-debromoconvolutamydine E (15) as a white solid (54\%).

HPLC (Daicel Chiralpak AD, flow rate $=0.8 \mathrm{~mL} / \mathrm{min}$, Hexane $/ i \operatorname{PrOH}=5 / 1,254 \mathrm{~nm}$ )

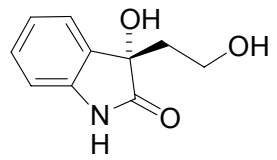

15

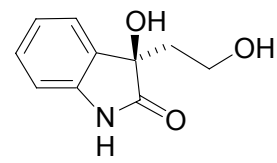

ent-15

Prepared from 8

$13.60 \mathrm{~min}$

Prepared from ent-12

$13.46 \mathrm{~min}$

Racemic

$13.44 \mathrm{~min}$

$16.83 \mathrm{~min}$

1) Sunazuka, T.; Hirose, T.; Shirahata, T.; Harigaya, Y.; Hayashi, M.; Komiyama, K.; Ōmura, S.; Smith, A. B. III. J. Am. Chem. Soc. 2000, 122, 2122-2123. 


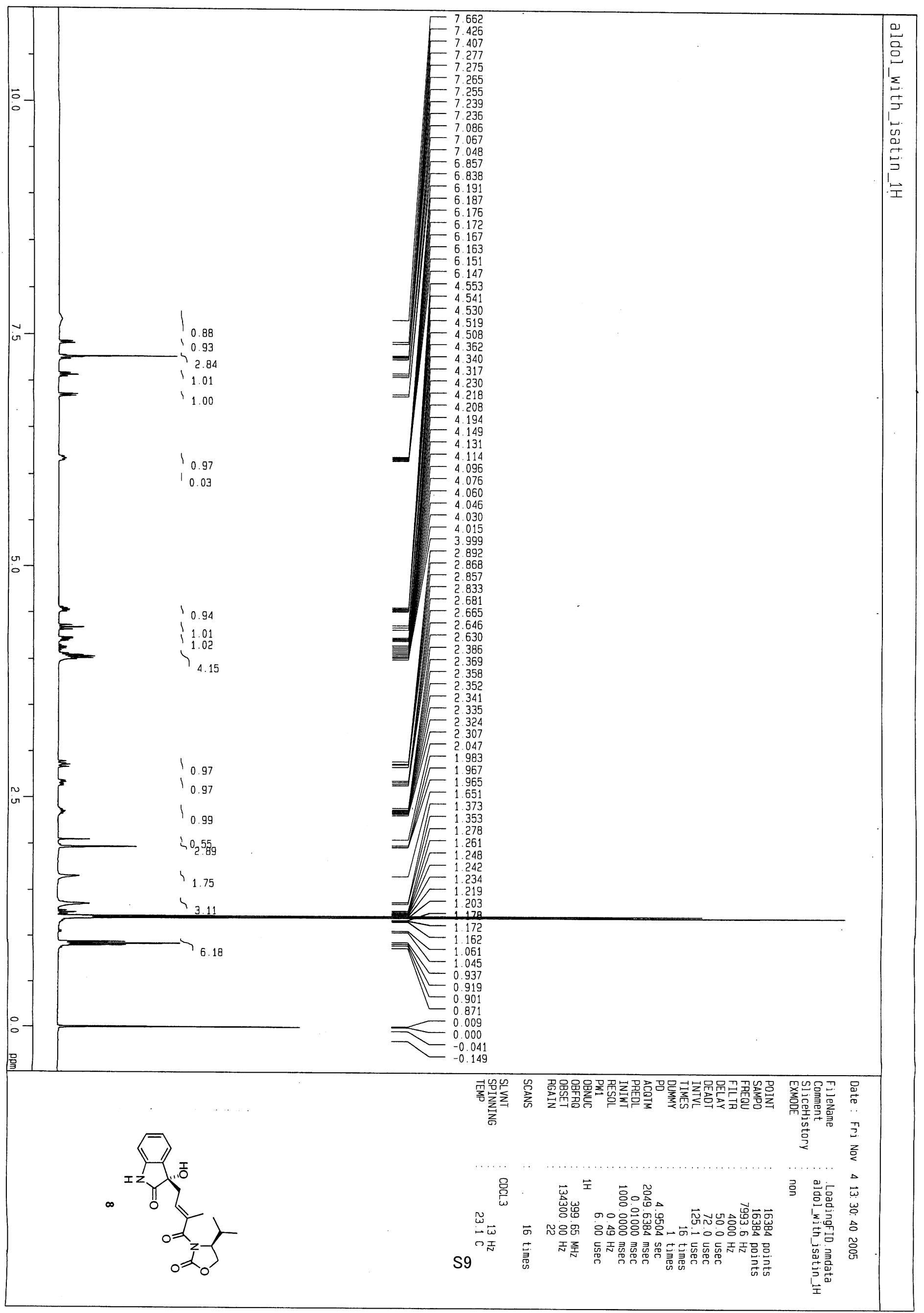




$$
\mid
$$




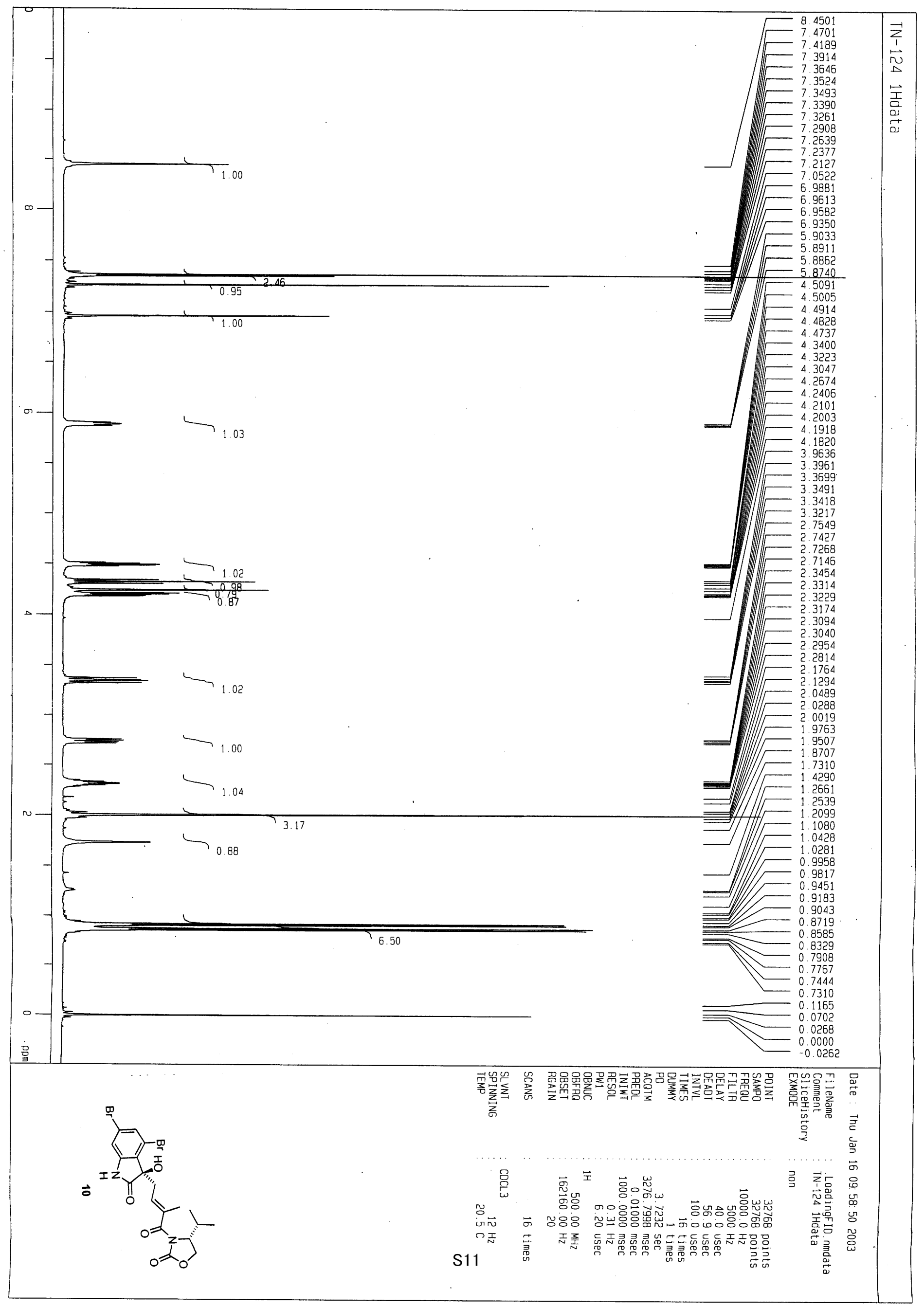




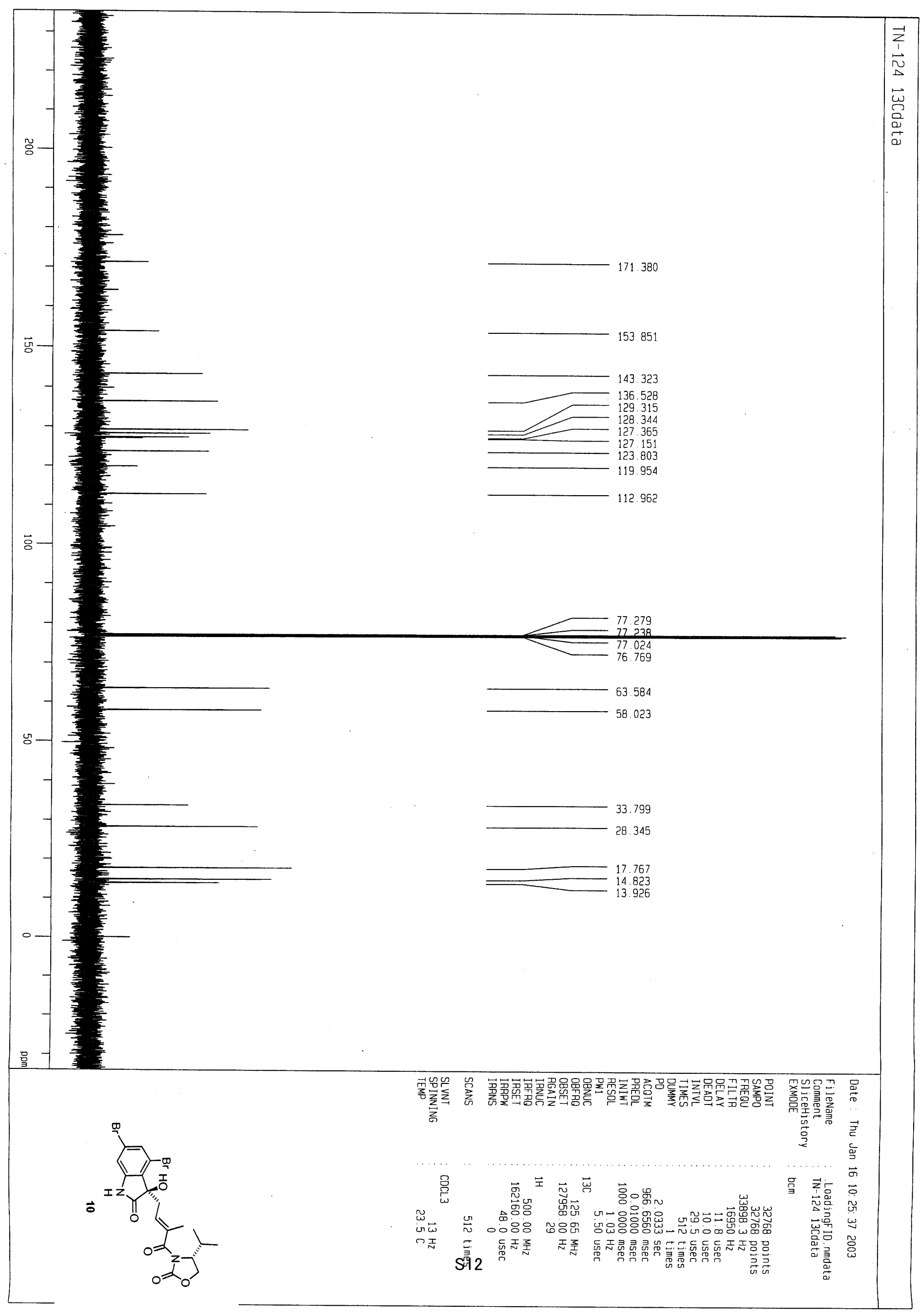




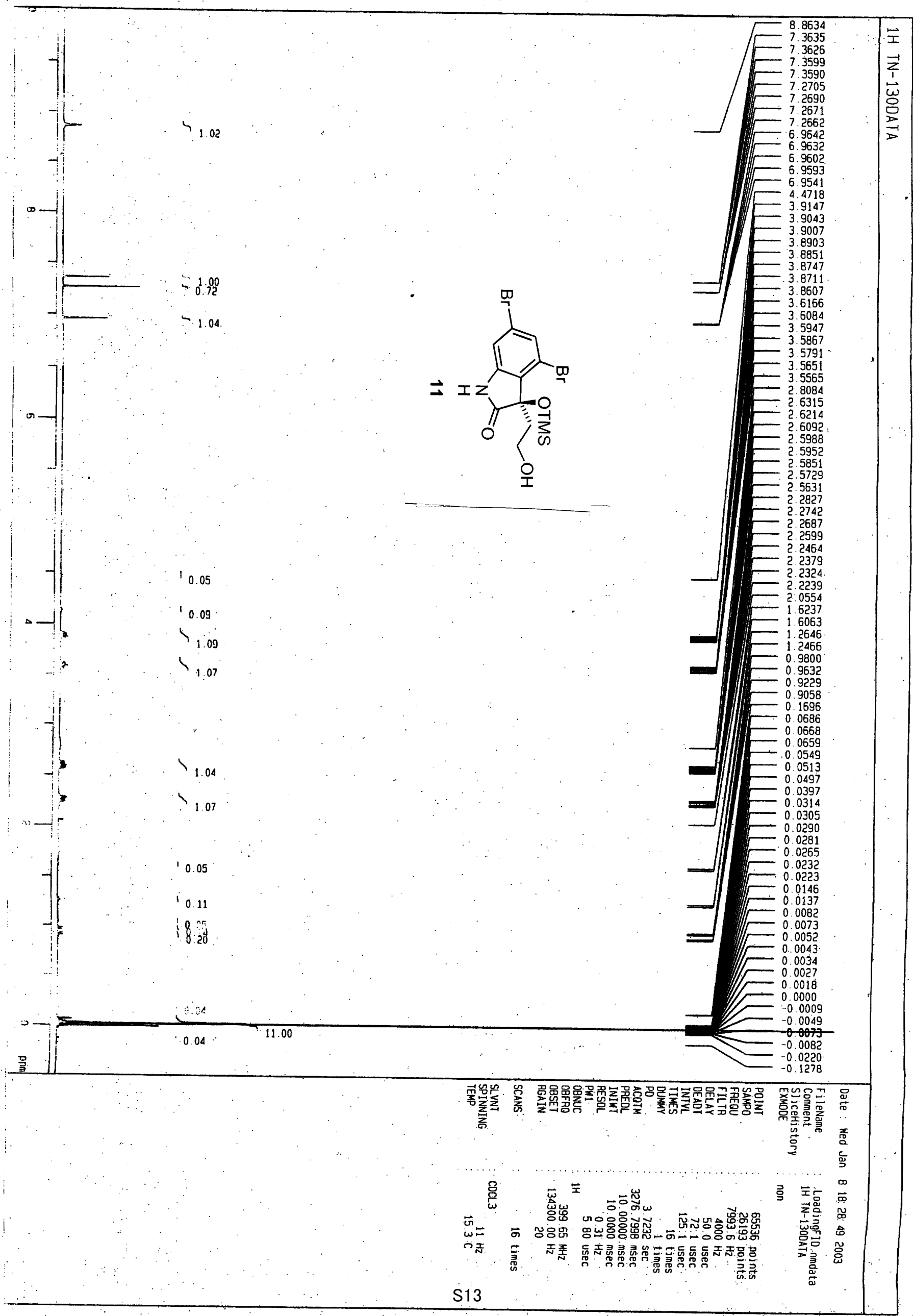




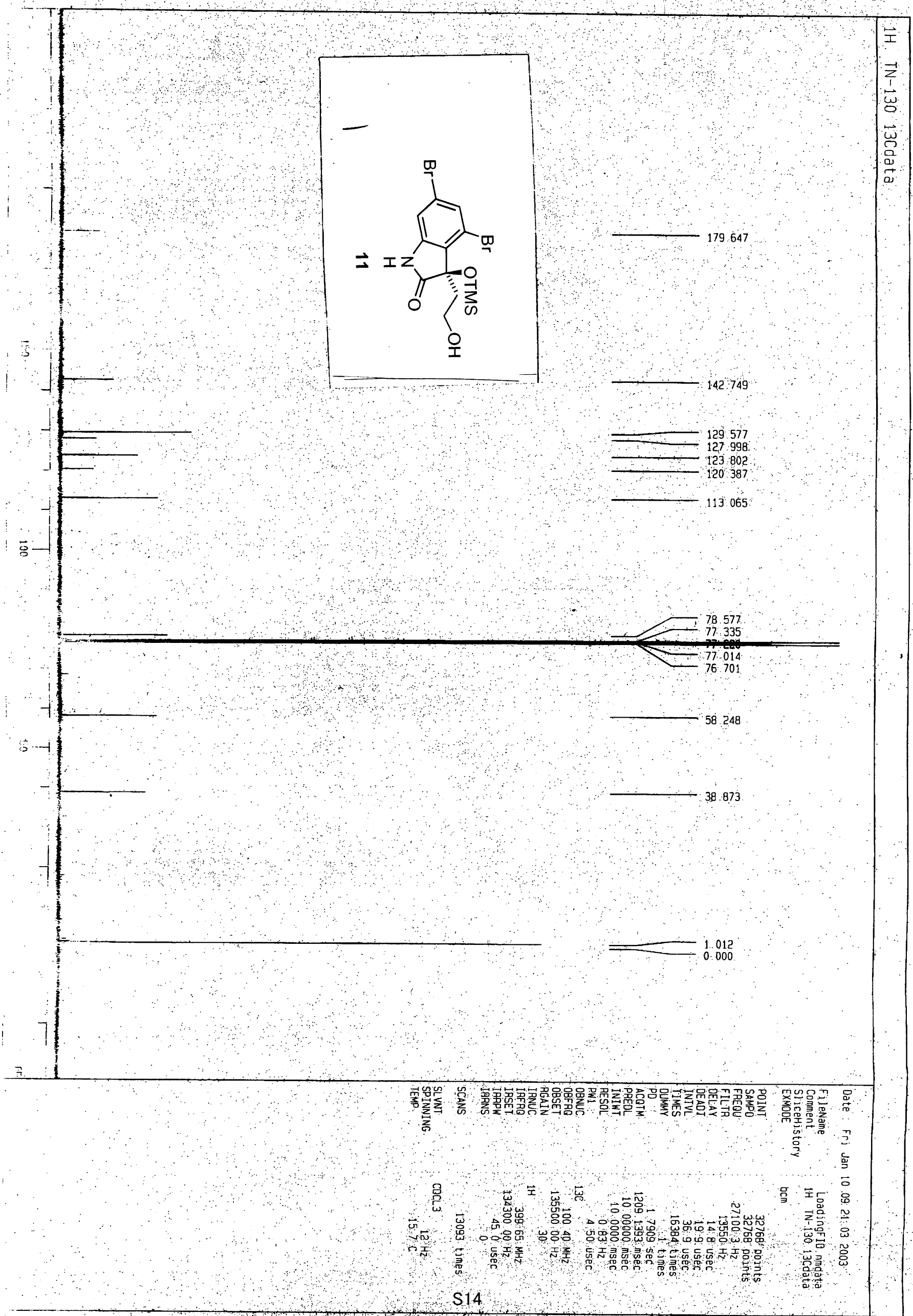




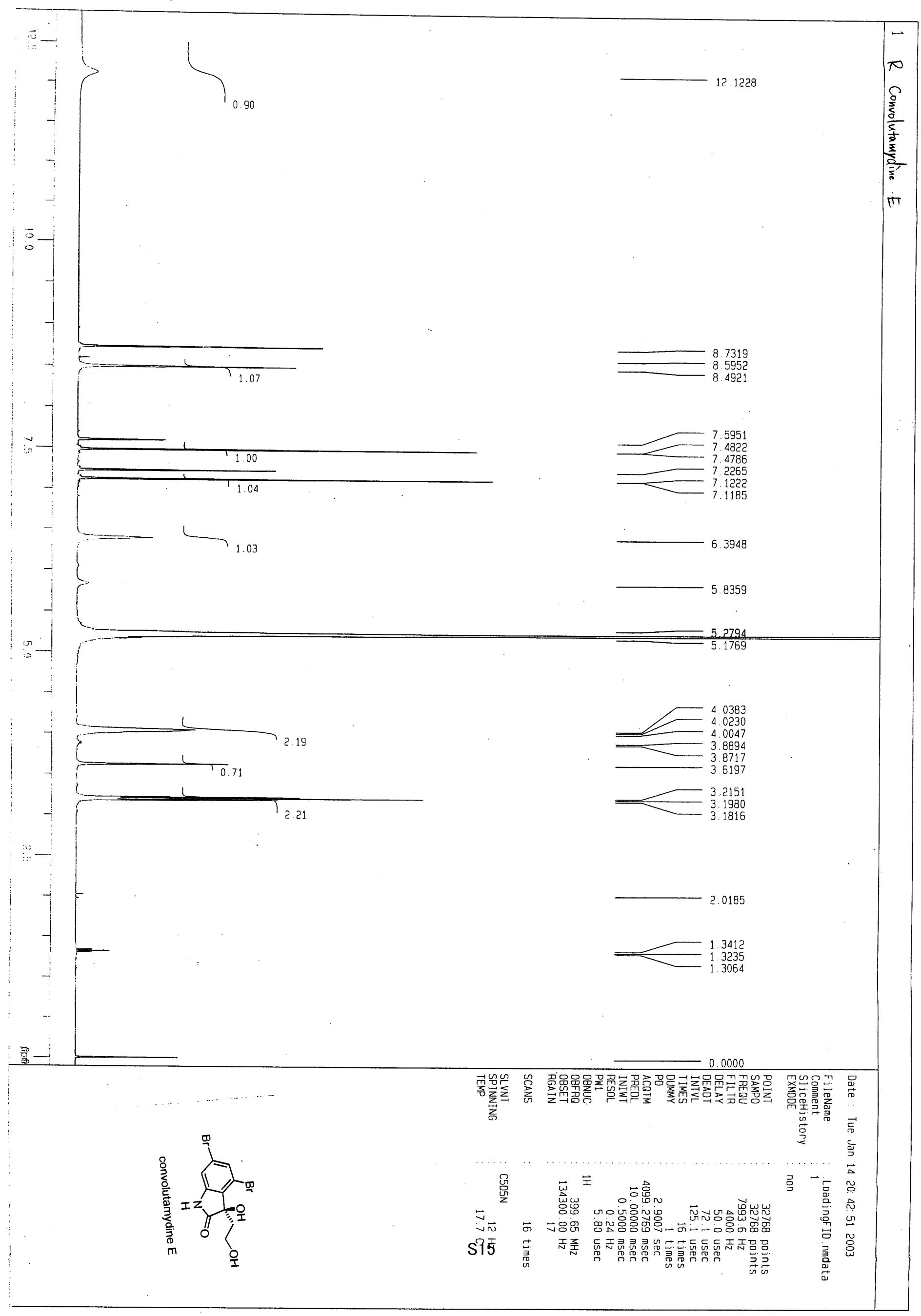




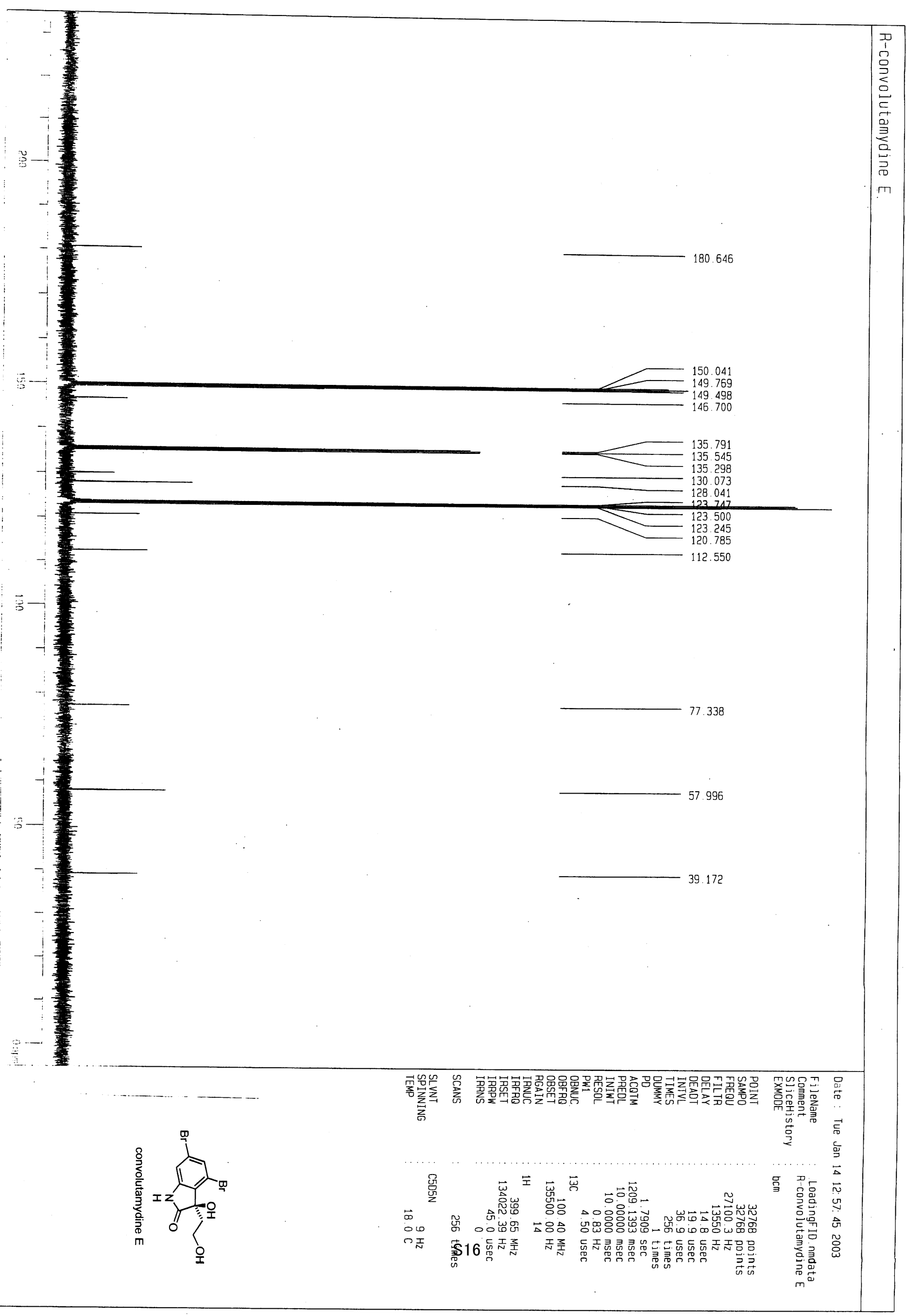




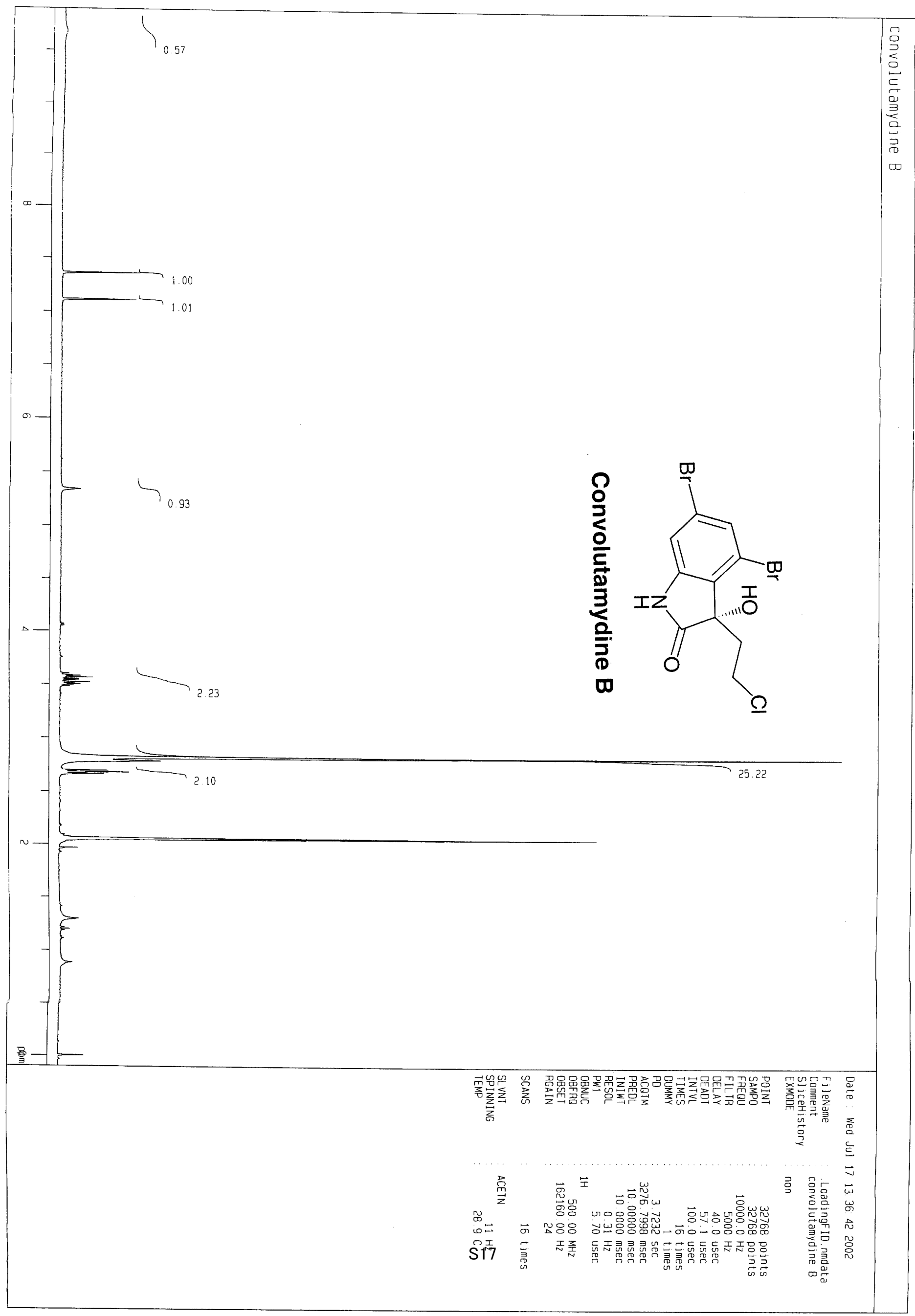




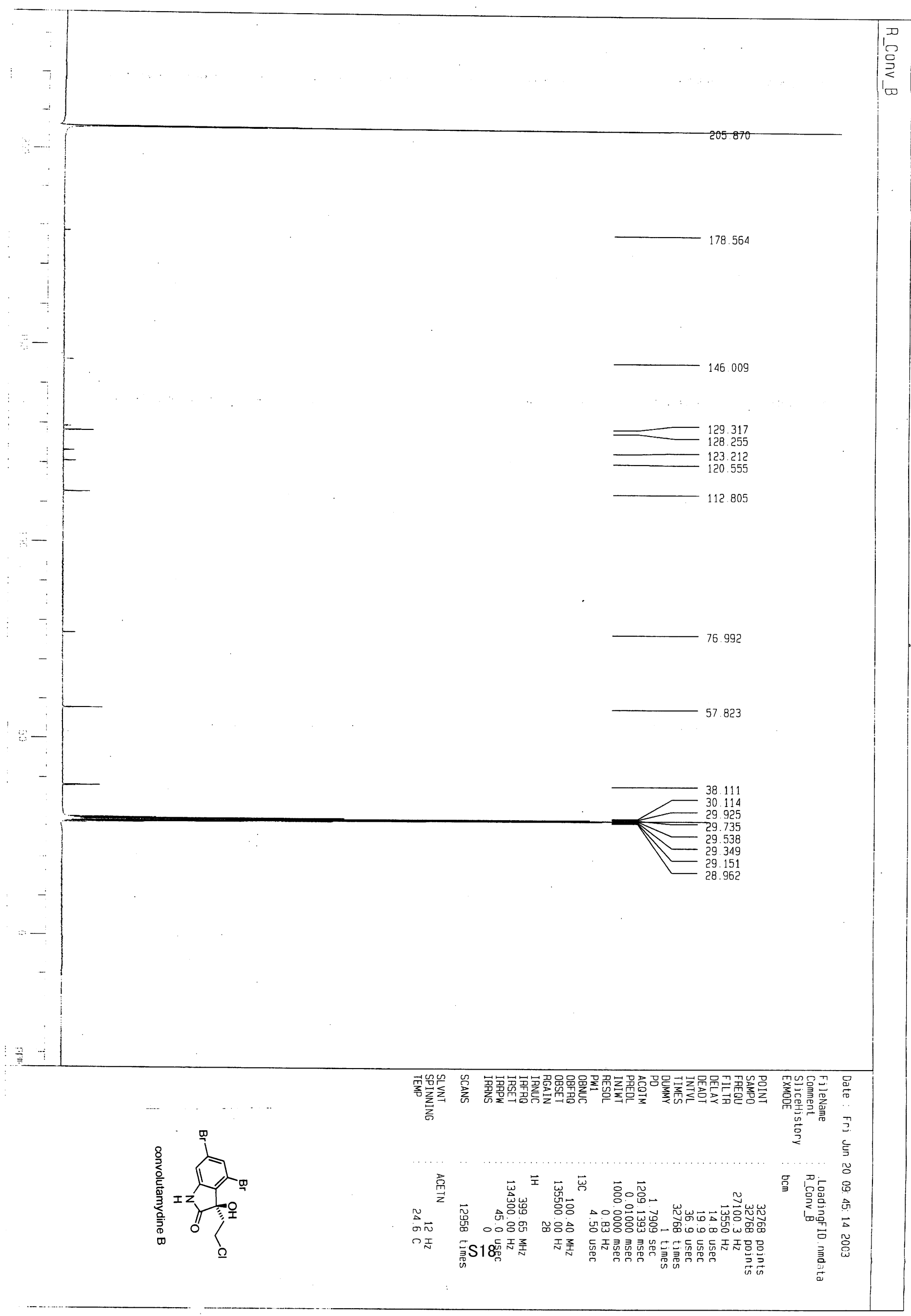




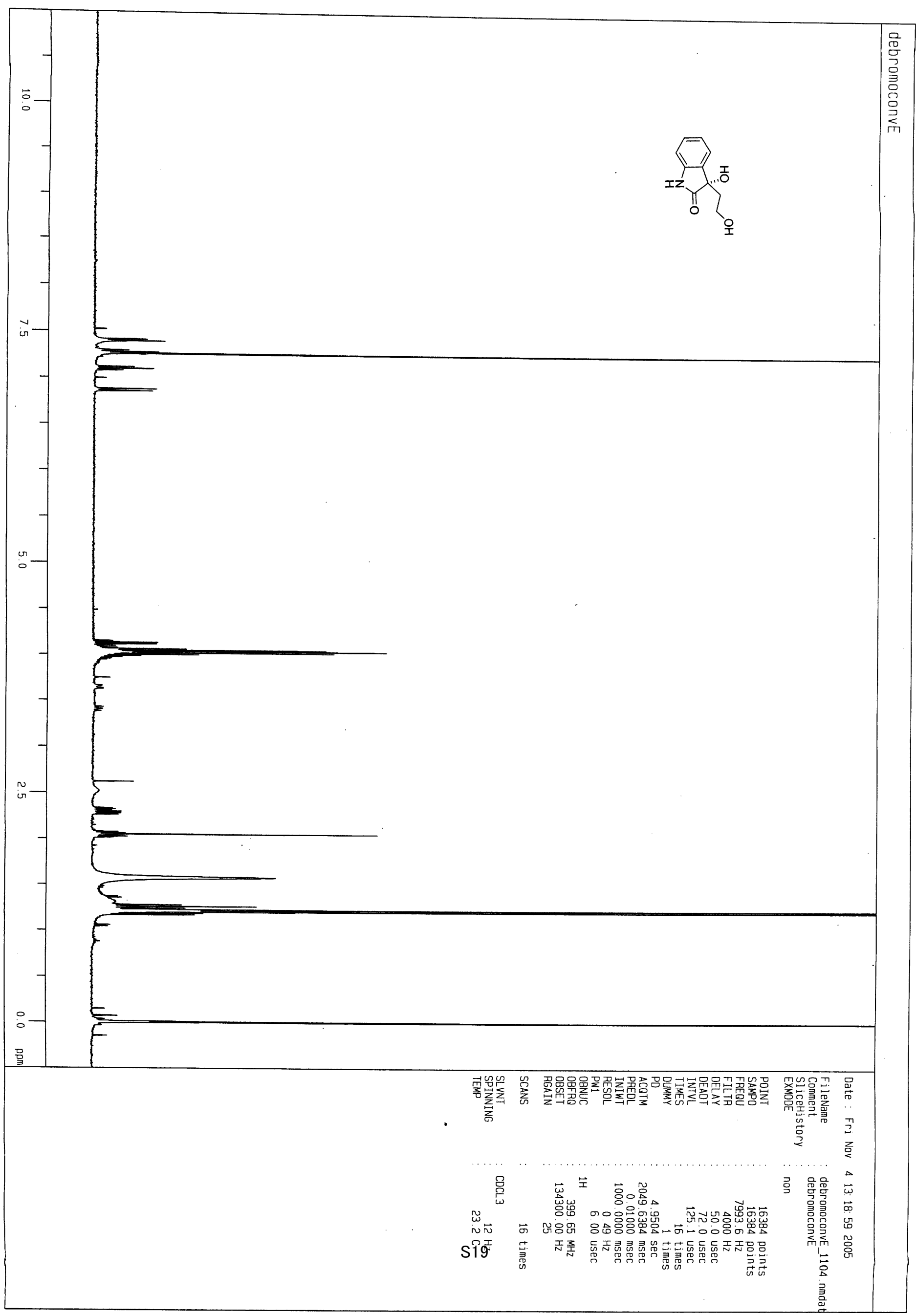




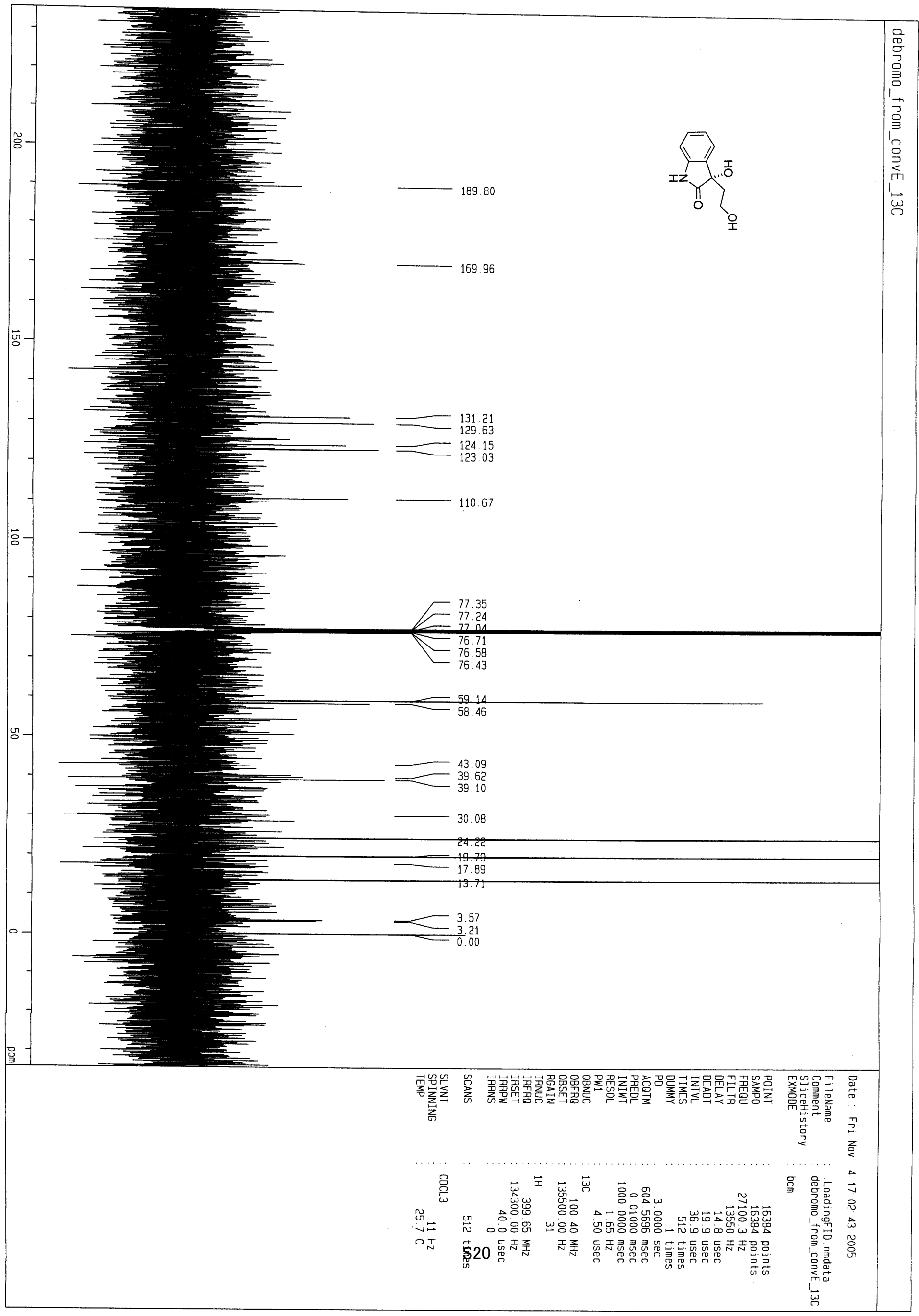


EH. 1 D.5 2.59 ATT 5 DFFS O
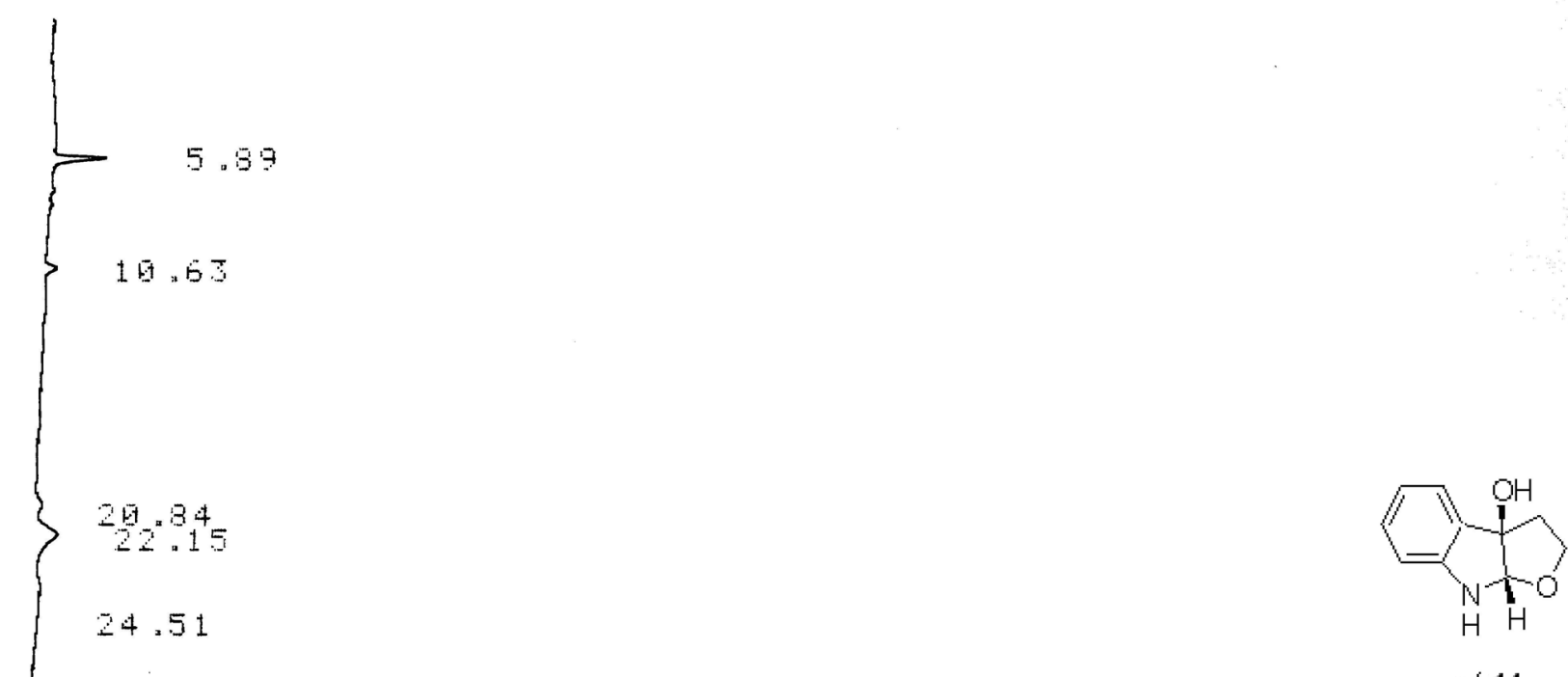

ent-14

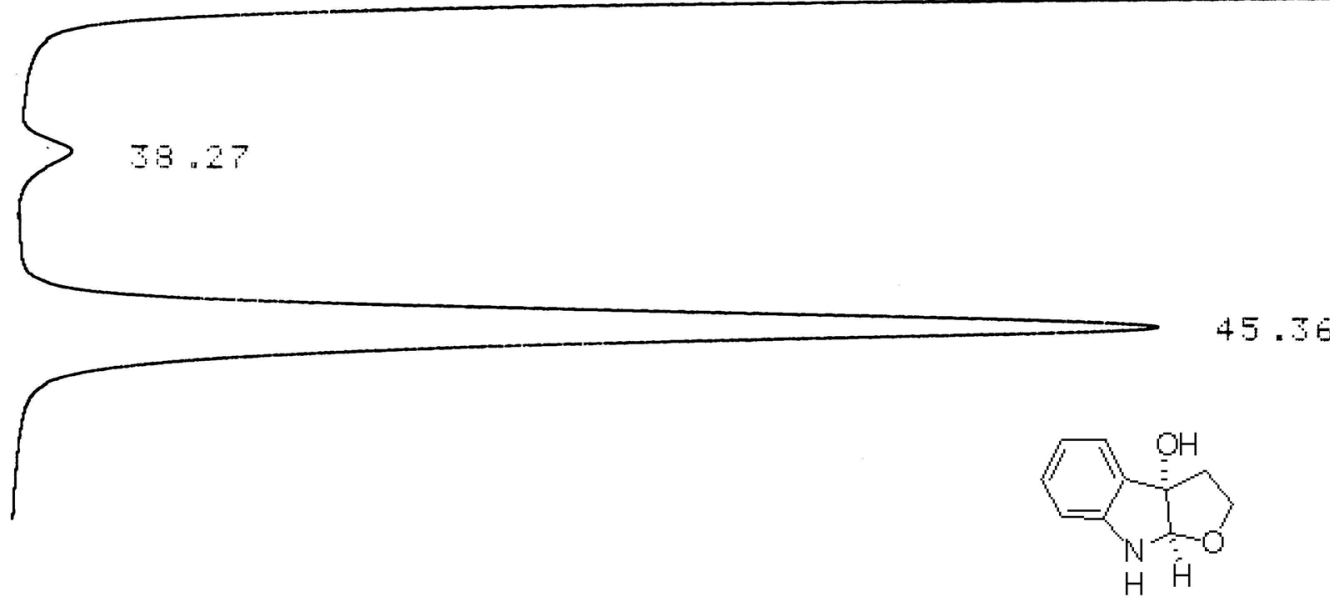

14

[1-250日

00000001034

METHOO :

THG:

$2 \quad \mathrm{CH}: 1$

FILE: Q GALC-METHDO: AREF\% THBLE:

\begin{tabular}{|c|c|c|c|}
\hline 40. & RT & AREA & EOHE \\
\hline 1 & 5.99 & 15578 & 0.296 \\
\hline 2 & 19.63 & 4969 & 9.108 \\
\hline$\overline{3}$ & 20.84 & 3200 & 0.070 \\
\hline 4 & 22.15 & 22364 & 0.487 \\
\hline 5 & 24.51 & 9480 & 0.266 \\
\hline 6 & 31.42 & 2218736 & 48.287 \\
\hline 7 & $58 \cdot 27$ & 84712 & 1.844 \\
\hline 8 & $45: 56$ & 2237846 & $48 \times 79$ \\
\hline
\end{tabular}

TOTAL

FEAK RE.J :

$4594885 \quad 1090000$ 


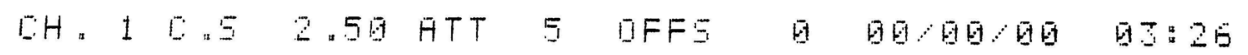

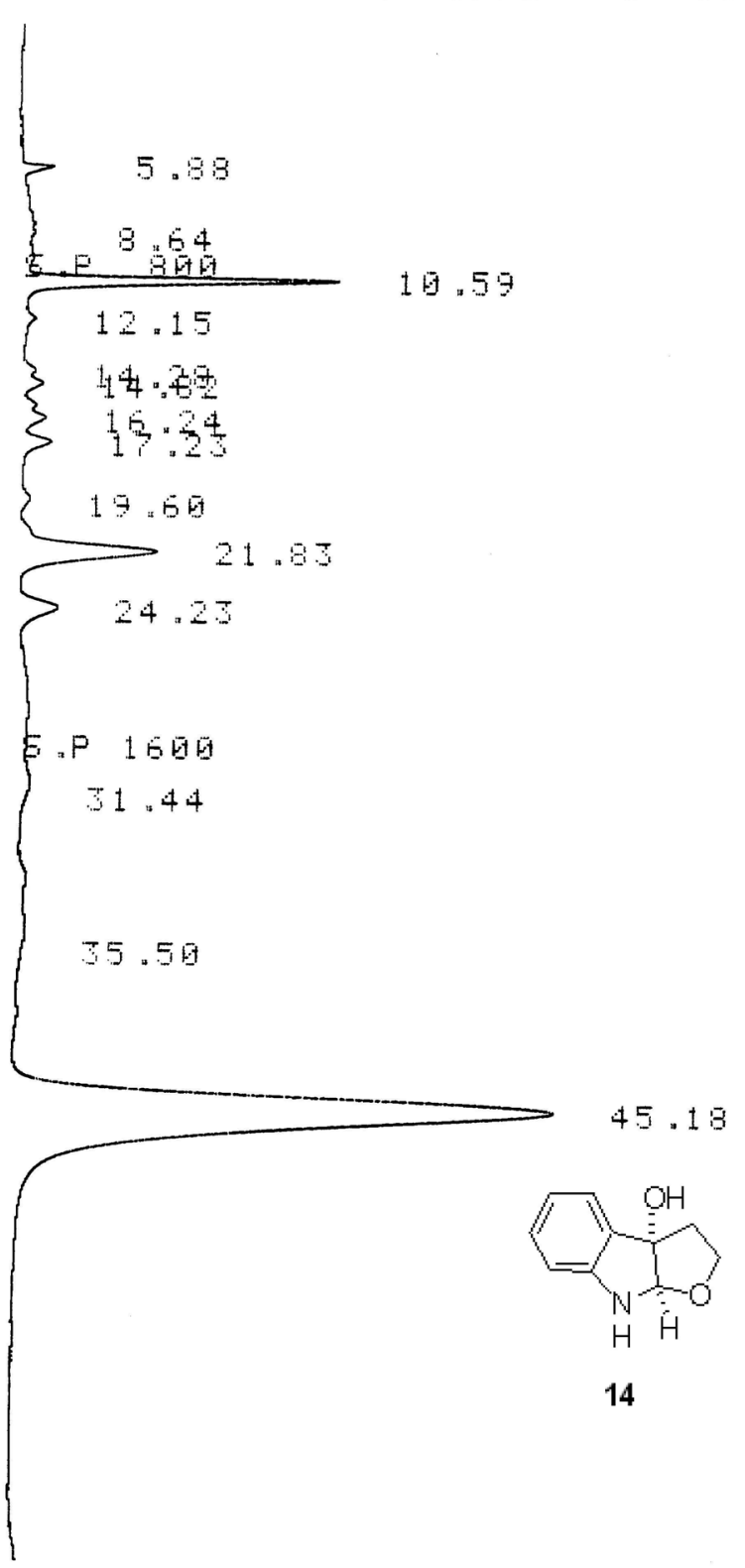

$[1-2509$

NETHOO:

THE: $\quad \mathrm{CH}: 1$

FILE: G ERL-METHOD: APEA\% TABLE: D COHE: AREA

\begin{tabular}{|c|c|c|c|c|}
\hline Ho. & $F T$ & HREA & EOHE & $\mathrm{ED}$ \\
\hline 1 & $5 \cdot 86$ & 9266 & 9.644 & $\mathrm{EE}$ \\
\hline 2 & 6.64 & 5000 & 0.348 & $\mathrm{BB}$ \\
\hline 3 & 10.59 & 119520 & 8.512 & $\mathrm{BB}$ \\
\hline 4 & 12.15 & 4222 & 0.294 & $\mathrm{BB}$ \\
\hline 5 & 14.28 & 5.57 & Q 9.575 & BU \\
\hline 6 & 14.62 & 19479 & 日.729 & पy \\
\hline 7 & 16.24 & 19792 & 1.79 & 1114 \\
\hline 8 & 17.23 & 17457 & 1.213 & $4 \mathrm{~B}$ \\
\hline 9 & 19.60 & 3913 & 9.265 & $\mathrm{BE}$ \\
\hline 10 & 21.63 & 199709 & 7.630 & $\mathrm{BB}$ \\
\hline 11 & 24.25 & 54254 & 2.382 & $\mathrm{BE}$ \\
\hline 12 & $31 \times 44$ & 9420 & 9.655 & $\mathrm{~EB}$ \\
\hline 1.3 & 35,50 & 30075 & 2.092 & $\mathrm{BE}$ \\
\hline $\begin{array}{l}14 \\
\mathrm{HL}\end{array}$ & 45.18 & 10596.36 & $\begin{array}{c}7.694 \\
\text { S22 }\end{array}$ & $\mathrm{BB}$ \\
\hline$E$ & : & $\begin{array}{c}1437990 \\
0\end{array}$ & 10日，日可 & \\
\hline
\end{tabular}




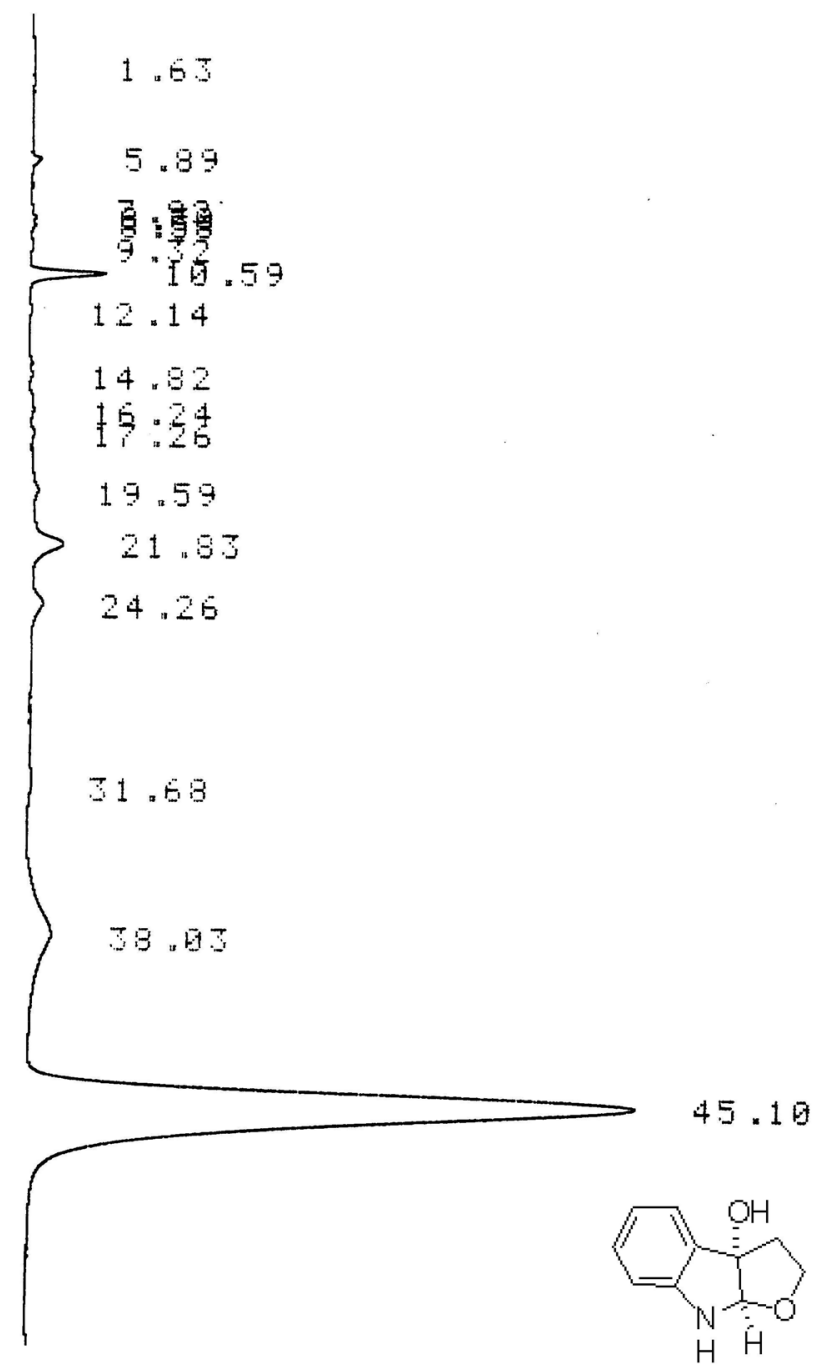

14

$[-2506$

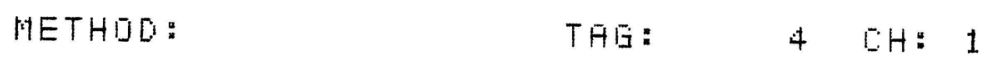

FILE: G CALE-METHOO: AREA\% THBLE: G DOHE: AREA

\begin{tabular}{|c|c|c|c|c|}
\hline HO。 & FT & AFEA & EDNE & $B E$ \\
\hline 1 & 1.63 & 10344 & 0.51 & $\mathrm{BE}$ \\
\hline 2 & 5.89 & 6236 & 日.20 & $\mathrm{BB}$ \\
\hline 5 & 7.92 & 597 & 0.022 & $\mathrm{BE}$ \\
\hline 4 & 8.30 & 2672 & 0.099 & Bu \\
\hline 5 & 8.58 & 2553 & 0.994 & UE \\
\hline$\theta$ & 9.32 & 1355 & 0.056 & $\mathrm{BE}$ \\
\hline 7 & 10.59 & 58627 & 2.159 & $\mathrm{BI}$ \\
\hline 8 & 12.14 & 1766 & 0.965 & TBE \\
\hline 9 & 14.82 & 5327 & 0.196 & $\mathrm{BE}$ \\
\hline 10 & 16.24 & 6981 & 0.257 & $\mathrm{BE}$ \\
\hline 11 & 17.26 & 3451 & 0.120 & $\mathrm{BE}$ \\
\hline 12 & 19.59 & 9462 & 日. 346 & $B E$ \\
\hline 15 & 21.85 & 52897 & 1.949 & $B E$ \\
\hline 14 & 24.26 & 19596 & 9.721 & $B E$ \\
\hline 15 & 31.68 & 8292 & 0.302 & $\mathrm{BE}$ \\
\hline 15 & 38.95 & 186124 & 6.853 & BU \\
\hline $\begin{array}{c}17 \\
T H L\end{array}$ & 45.19 & 2339893 & $\begin{array}{l}85 \times 151 \\
S 23\end{array}$ & U \\
\hline & 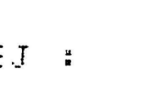 & $\begin{array}{c}271647 \\
6\end{array}$ & 10日.日日日 & \\
\hline
\end{tabular}




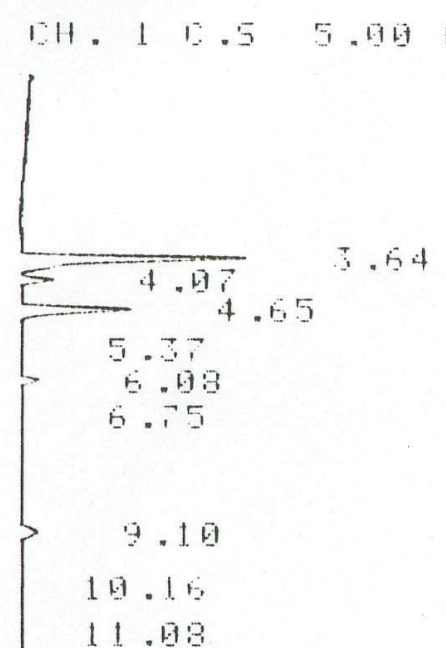

1) $9409091: 54$

11.98

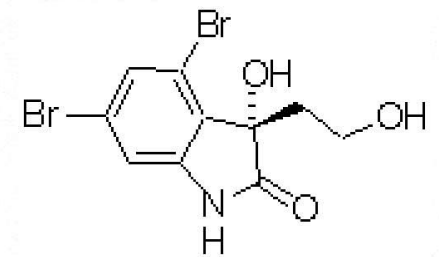

ent-12

15.92

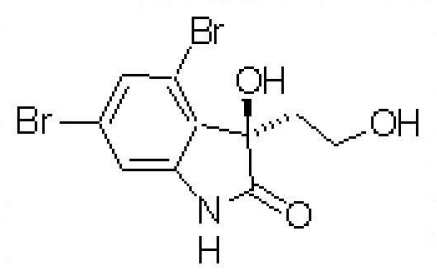

12

$[1-2506$

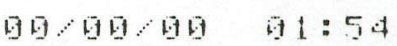

METHO[:

THG:

2 EH: 1

FILE: Q DHLE-METHDO: APEA\% TABLE: D COHE: AREA

\begin{tabular}{|c|c|c|c|c|}
\hline HO. & PT & AREA & EOHE & $\mathrm{Bi}$ \\
\hline 1 & 3.64 & 20513 & 1. 213 & BU \\
\hline 2 & 4.07 & 3320 & 9.196 & 118 \\
\hline 3 & 4.55 & 13382 & 9.791 & BU \\
\hline 4 & 5.37 & 434 & 0.926 & TBE \\
\hline 5 & 6. 08 & 3297 & 0.195 & $B E$ \\
\hline$B$ & 6.75 & 740 & 0.044 & $B E$ \\
\hline $\overrightarrow{7}$ & 9.10 & 6818 & 0.403 & $\mathrm{BB}$ \\
\hline 8 & $1 日 .16$ & 16.32 & 日. 996 & $\mathrm{BE}$ \\
\hline 9 & 11.09 & 5042 & 0.298 & $\mathrm{BB}$ \\
\hline 10 & 15.62 & 794291 & 45.963 & Eu \\
\hline 11 & 19.59 & 841819 & 49.774 & 118 \\
\hline
\end{tabular}

TOTAL

FEAK FET :

1691277

日

1 1. 
EH. 19.5 .

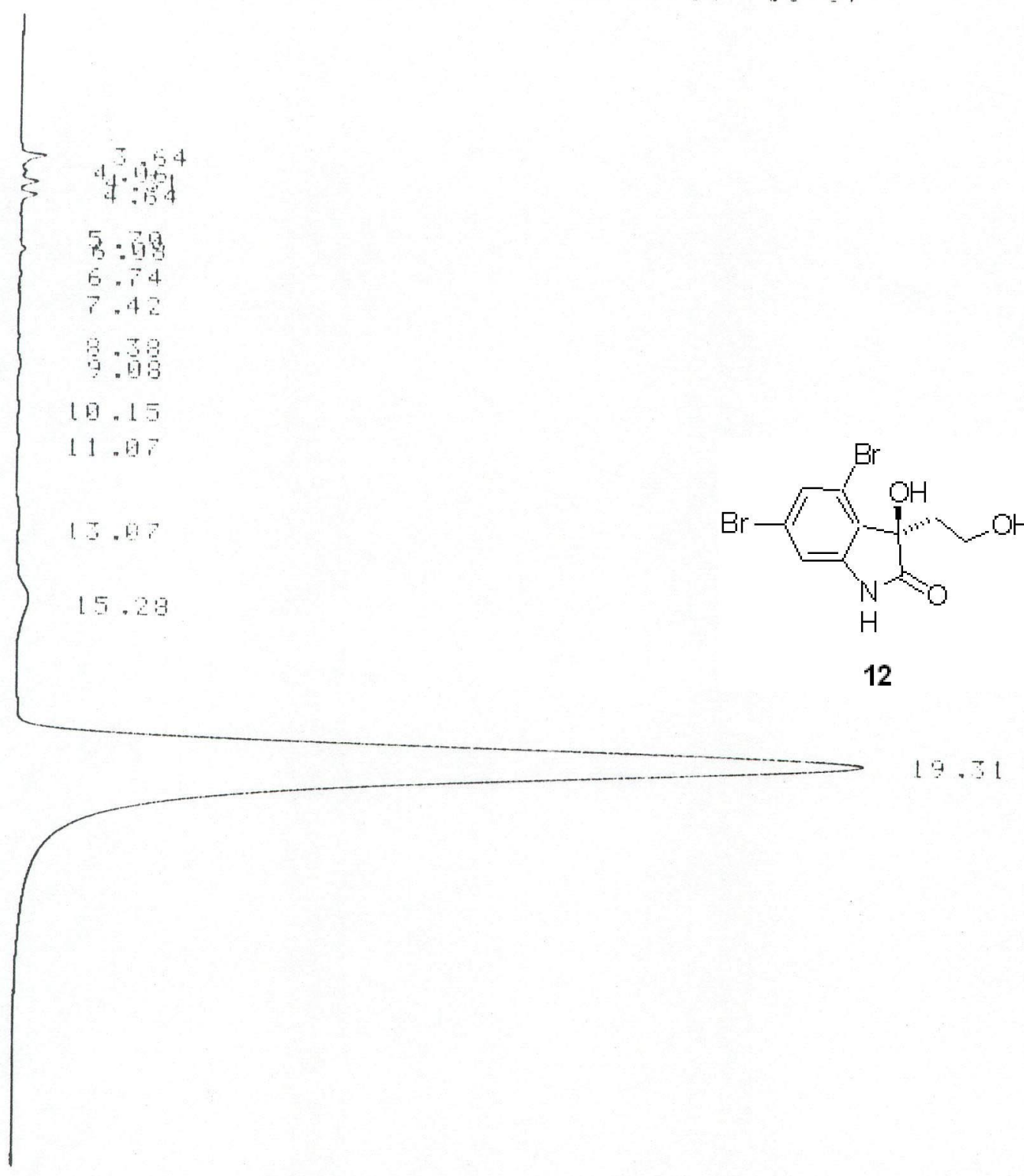

$[1-2561$

19日20060

METHOO:

THE: 4 L EH: :

FILE: 日 DALE-METHOD: AFEA\% TABLE: G DOHE: APEA

\begin{tabular}{|c|c|c|c|c|}
\hline 110. & FT & HFEA & cints & $\mathrm{EC}$ \\
\hline 1 & 3.54 & 16911 & 9.5 .51 & EU \\
\hline 2 & 4.96 & 3562 & 0.112 & 1111 \\
\hline 3 & 4.31 & 8690 & 9.273 & 410 \\
\hline 4 & 4.64 & 16099 & 9.917 & $\| E$ \\
\hline 5 & 5.70 & 221 & 9.9日7 & $\mathrm{BE}$ \\
\hline 6 & 6.18 & $3 \div 79$ & 0.105 & BE \\
\hline 7 & 5.74 & 1169 & 9.037 & $\mathrm{BB}$ \\
\hline 8 & 7.42 & 1678 & 0.034 & $\mathrm{~EB}$ \\
\hline 9 & 8.53 & 501 & 9.916 & $B E$ \\
\hline $1 \mathrm{~B}$ & 9.98 & 5027 & 19.975 & $E E$ \\
\hline 11 & 10.15 & 1387 & 6. 1.44 & $E B$ \\
\hline 12 & 11.67 & 1242 & 0.9525 & $\mathrm{EE}$ \\
\hline 13 & 15,87 & 3271 & 9.10 .5 & $\mathrm{EE}$ \\
\hline 14 & 15.23 & 4579 & $1 \ldots 7$ & EU \\
\hline $\begin{array}{r}15 \\
\text { I } \mathrm{HL}\end{array}$ & 19.51 & 3689472 & 96.915 & $11 \mathrm{E}$ \\
\hline
\end{tabular}




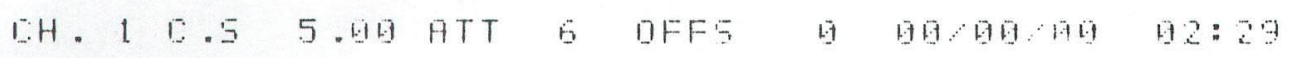

$4^{3}=0$

6.198

$\vec{i}, \overline{3}$

9.96

1.12

11.55

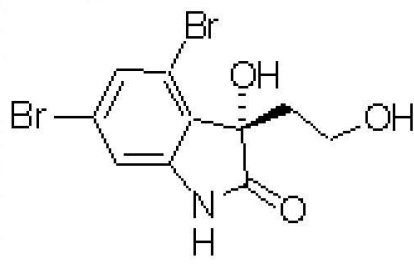

ent- 12

14.96

$[1-2506$

月日.

METHOD:

THĪ:

J LH:

FILE: D DALC-METHOD: HPEA\% TABLE:

\begin{tabular}{|c|c|c|c|c|}
\hline HO. & FT & AFEE & EDHE & $\mathrm{BE}$ \\
\hline 1 & 3.65 & 7.513 & 0.302 & BU \\
\hline 2 & 4.66 & 1690 & 0.068 & 414 \\
\hline 5 & 4.29 & 997 & 0.040 & 118 \\
\hline 4 & 4.64 & 4492 & 0.191 & $\mathrm{BE}$ \\
\hline 5 & 6.08 & 5617 & 0.145 & $\mathrm{BE}$ \\
\hline 6 & 7.35 & 2190 & 0.088 & $\mathrm{BB}$ \\
\hline 7 & 9.08 & 6654 & 0.267 & - E 11 \\
\hline 8 & 19.12 & 2505 & 0.101 & 48 \\
\hline 9 & 11.55 & 17572 & 9.796 & $\mathrm{BE}$ \\
\hline 19 & $14.8 \mathrm{~B}$ & $2+14123$ & 97.640 & BU \\
\hline 11 & 19.72 & 26266 & 1.056 & TBE \\
\hline
\end{tabular}

TOTAL

PEAK PE.T:

$2487624 \quad 109.900$

B) 


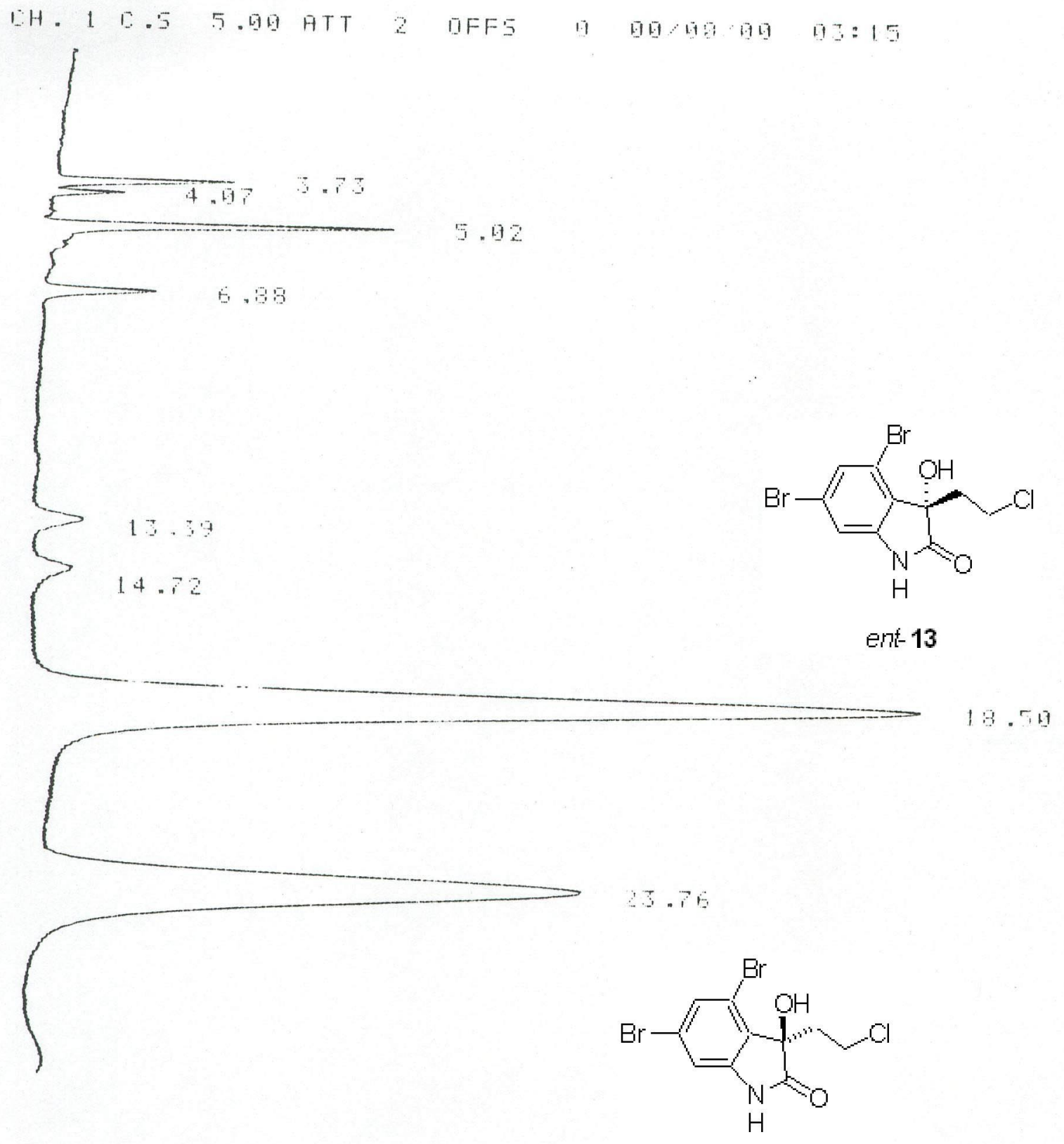

13

$[1-251] 6$

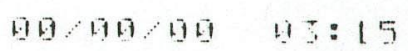

METHOD:

TḦi :

$3 \quad$ I:H: 1

FILE: 日 LALE-METHOD: APEA\% TABLE: G GOHE: APEH

\begin{tabular}{|c|c|c|c|}
\hline HI. & PT & APEA & EDHE \\
\hline 1 & 3.73 & $56 日 0$ & 1.983 \\
\hline 2 & 4.67 & 1658 & 0.587 \\
\hline 3 & 5.92 & 12498 & 4.425 \\
\hline 4 & 5.38 & 4498 & 1.575 \\
\hline 5 & 13.59 & 4320 & 1.5 .5 \\
\hline 5 & 14.72 & 5852 & 1.364 \\
\hline 7 & 18.56 & 141962 & 50.251 \\
\hline 8 & 23.76 & 108132 & 35.289 \\
\hline
\end{tabular}

FEAI RE.T :

$282420 \quad 109.000$

日) 


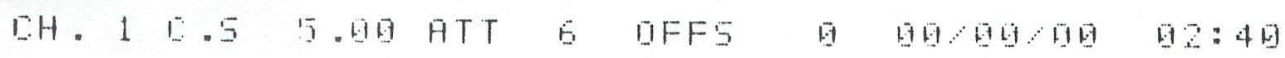

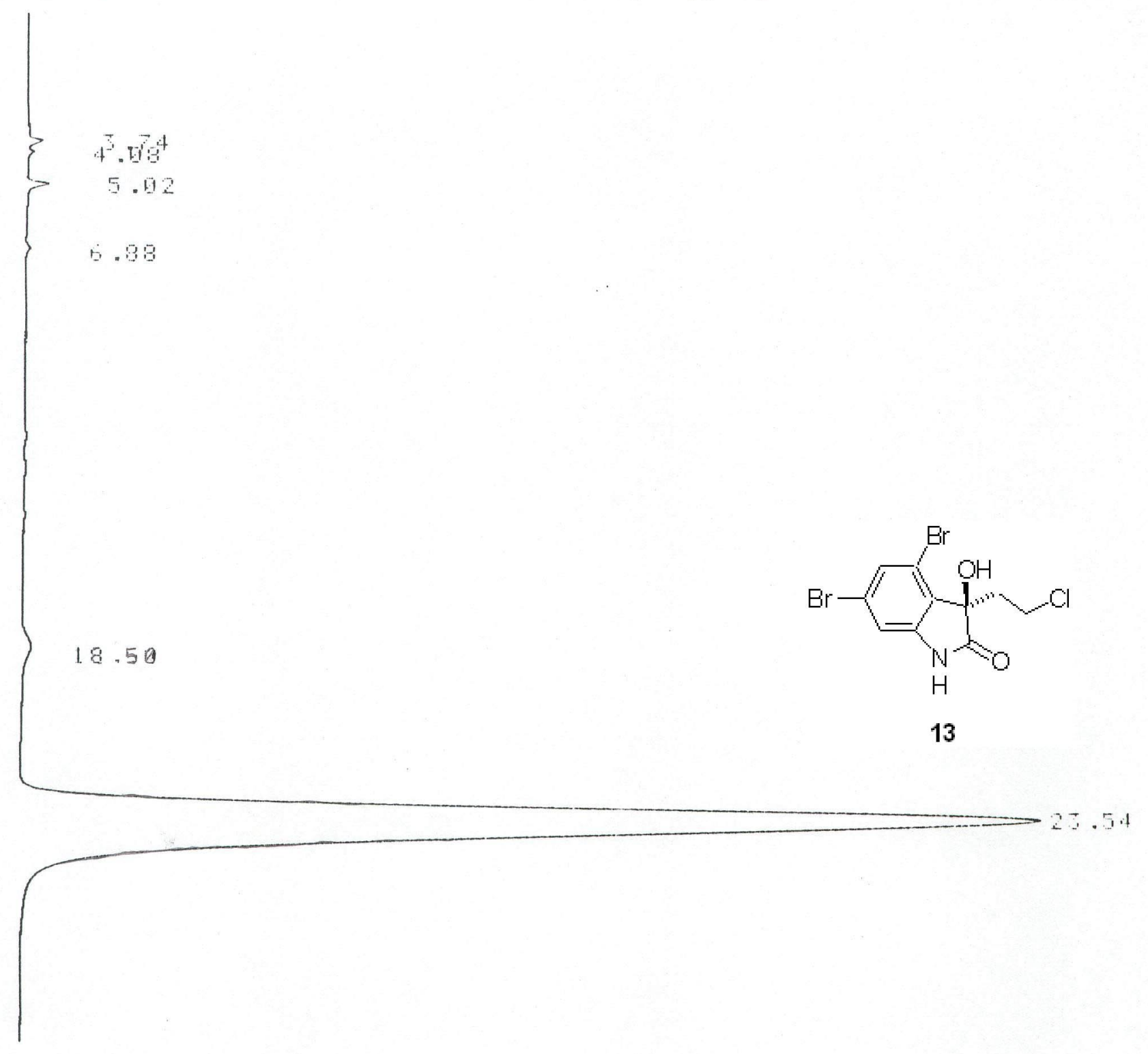

[1-25日田

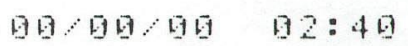

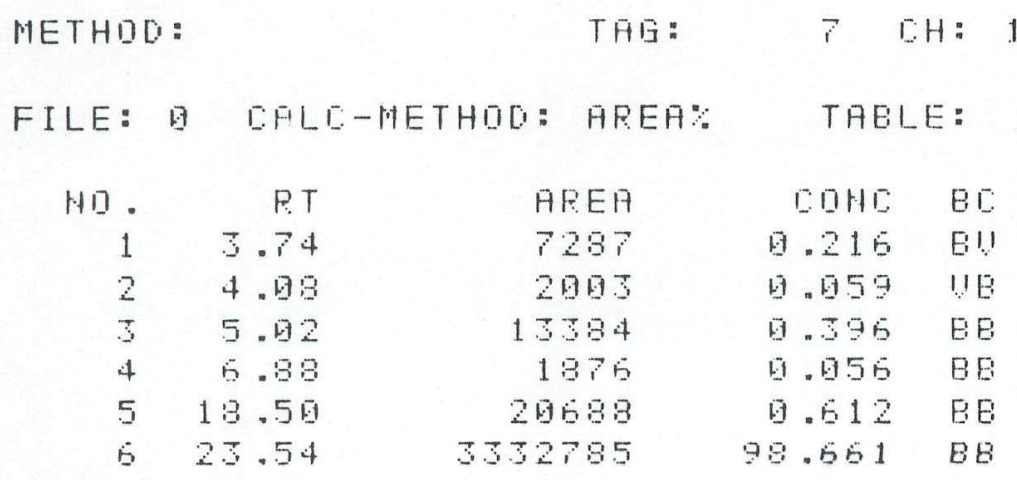

PEAK RE.J :

$3378023 \quad 100.900$

1) 


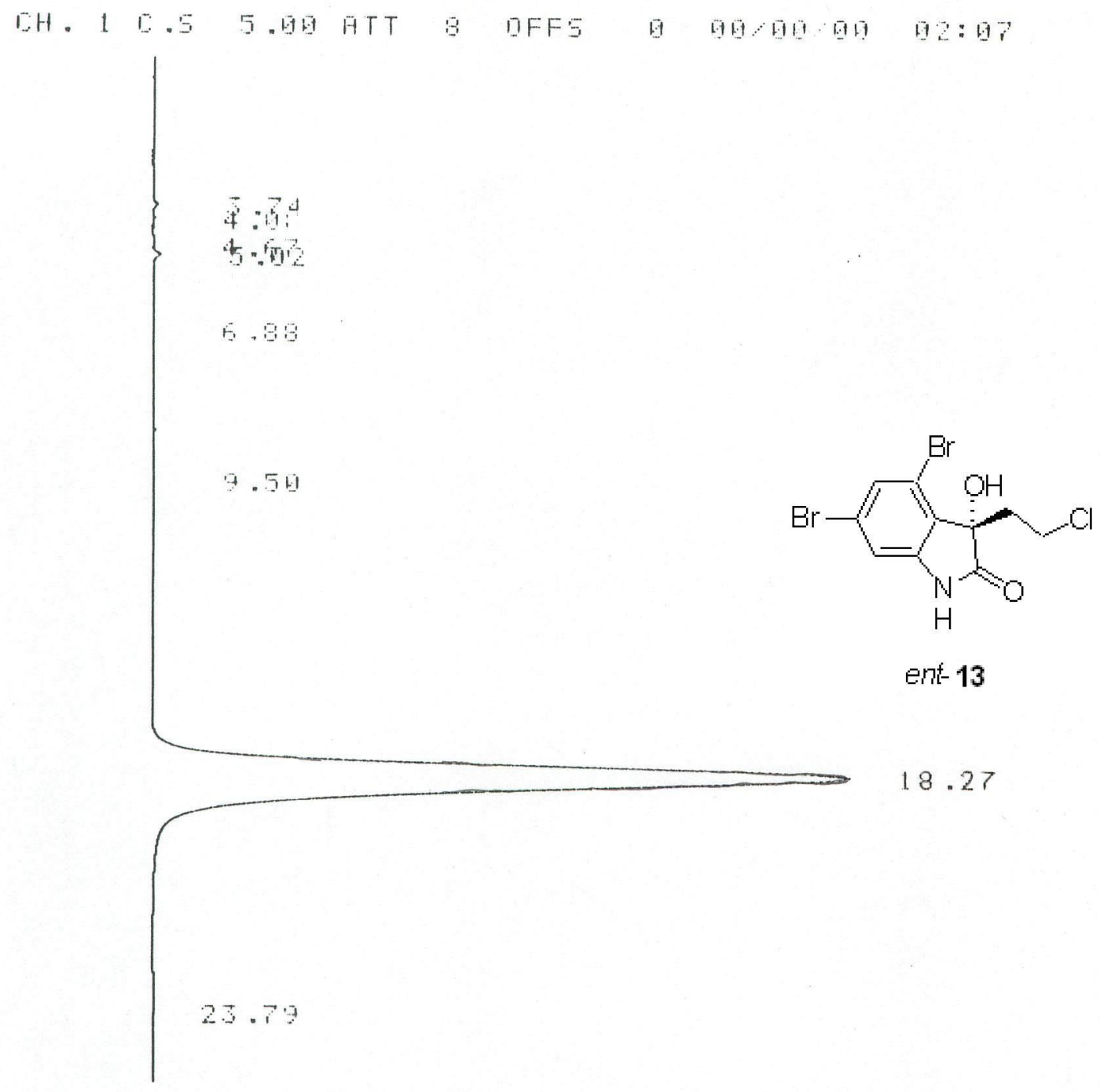

$[1-2.56$ 日

9日9日20日

METHOD:

TAF:

$6 \quad$ CH: 1

FILE: G CAI D-METHOD: AFEH\% THBLE: G EOHE: HPEA

\begin{tabular}{|c|c|c|c|}
\hline HO. & P.T & $A F E \bar{B}$ & EOHE \\
\hline 1 & 3.74 & 7406 & 0.115 \\
\hline 2 & 4.09 & 1755 & 0.028 \\
\hline 3 & 4.67 & 1010 & 0.016 \\
\hline 4 & 5.92 & 14206 & 日, 92 \\
\hline 5 & 5.88 & 250.8 & 0.63 \\
\hline 6 & 9.50 & 6193 & Q. 097 \\
\hline$\vec{i}$ & 13.27 & 6328832 & 99.336 \\
\hline 3 & $\therefore 5.79$ & 9391 & 日.147 \\
\hline
\end{tabular}

TOTAL

PEAK PEI :

$657199 \quad 1090969$

日 